\title{
Research Paper \\ Exploring and Identifying the Components of Teacher-Child Interaction Process Quality: A Qualitative Research
}

Sakineh Rahpeyma Aghmiuni' ${ }^{1}$, Fariborz Dortaj ${ }^{* 2}$, Aboutaleb Seadatee Shamir ${ }^{3}$, Khadijeh Abolmaali ${ }^{4}$

1. Ph.D. Student of Educational Psychology, Department of Educational Psychology, Science and Research Branch, Islamic Azad University, Tehran, Iran

2. Professor, Department of Educational Psychology, Faculty of Psychology and Educational Sciences, Allameh Tabataba'i

University, Tehran, Iran

3. Assistant Professor, Department of Psychology, Science and Research Branch, Islamic Azad University, Tehran, Iran 4. Associate Professor, Department of Psychology, Roudehen Branch, Islamic Azad University, Roudehen, Iran

Citation: Rahpeyma Aghmiuni S, Dortaj F, Seadatee Shamir A, Abolmaali K. Exploring and identifying the components of teacher-child interaction process quality: a qualitative research. J Child Ment Health. 2021; 8 (2):62-77.

URL: http://childmentalhealth.ir/article-1-1121-en.html
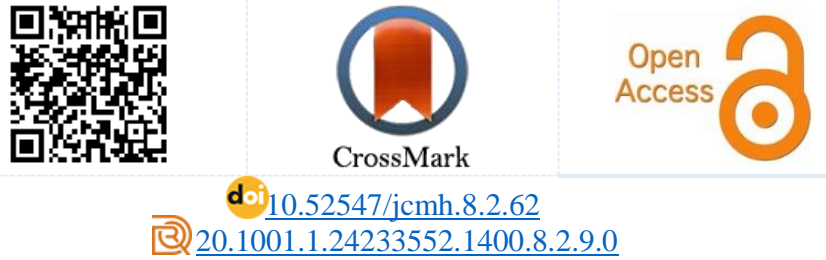

A R T I C L E I N F O

Keywords:

Process quality, educator-children interaction, kindergarten

\section{A B S T R A C T}

Background and Purpose: The quality of the interaction process between the child and the teacher considering the sensitivity, ease of effectiveness, stability, and depth of learning of children in this period will facilitate the educational process and better achieve the goals of the education system. Therefore, the present study aimed to explore and identify the components of the process quality of teacher-child interaction in kindergartens in Tehran.

Method: This research was conducted by qualitative method with the descriptive phenomenological approach in 2020. To this end, ten educators for the age group of four to six years in Tehran were selected by homogeneous sampling method and eight faculty members were selected through snowball purposive sampling that continued until saturation. Data were collected by semi-structured interview and then coded and analyzed by Colaizzi's method. The validity of qualitative data has been confirmed using four judgment criteria of Lincoln and Guba, the reliability of qualitative data has also been confirmed through test-retest reliability (validity index) and intercoder agreement (intra-subject agreement).

Results: By analyzing the data, 22 sub-themes and 6 main themes were extracted, the main themes are: individual characteristics, positive emotional climate, supportiveness, learning opportunities, group participation, and behavior management.

Conclusion: The results of this study showed that educators have a crucial role in providing conditions and opportunities for the optimal development of children, that is related to the educatorchildren interaction process quality. The implications of the results are discussed in the article.
Received: 14 Mar 2021

Accepted: 10 Jun 2021

Available: 22 Sep 2021

* Corresponding author: Fariborz Dortaj, Professor, Department of Educational Psychology, Faculty of Psychology and Educational Sciences, Allameh Tabataba'i University, Tehran, Iran.

E-mail: F_dortaj@yahoo.com

Tel: $(+98) 214453213$

2476-5740/ (C) 2021 The Authors. This is an open access article under the CC BY-NC-ND license

(https://creativecommons.org/licenses/by-nc-nd/4.0/). 


\section{Quarterly Journal of}

\section{Extended Abstract}

\section{Introduction}

Childhood is the most important and significant period of human life for the development of basic and motor skills. Due to the considerable speed of development in these ages, qualitative caring and appropriate learning experiences are considered the basic needs of children in this period (1). Therefore, educational policies should be towards designing quality learning environments (3). In centers, quality is focused on two dimensions of process and outcome. First, they focus on the quality of ongoing actions and reactions between educators and children, and then they focus on the quality of children's developmental status, abilities, disabilities, and behaviors. Therefore, by investing in the quality of the interaction process, we can expect the outcome (children) to be of good quality (5). Several components have been emphasized in reviewing research on the educator-children interaction process quality, including creating an atmosphere of respect and intimate relationships $(12,13)$, educator presence in children's activities (14), planning educational activities tailored to children's characteristics (15) Providing appropriate feedback (17) and using positive guidance methods in the face of misbehavior (18, 19). A study by Zarei et al. (21) concluded that individual characteristics such as well-groomed, classroom skills with patience, flexibility, and kindness have a great impact on the quality of interactions and attracting children. The research of Layzer and Goodson suggested that the ability to recognize the individual needs of children and respond in a positively is an effective factor in quality (22). Pianta and Hummer have emphasized the role of emotional support through intimate relationships with children, and mutual respect in the quality of the educator-children interaction process (24).

Since much study has not been done on the quality of the educator-children interaction process in Iran, this study was conducted to exploring and identifying the components of the educator-children interaction process quality.

\section{Method}

This qualitative research has been using the phenomenological approach. The present study population consisted of kindergarten teachers of four to six-year-old children in Tehran in 2020 and university faculty members with doctoral degrees in psychology and pre-school education. The sampling method of educators was purposive sampling based on inclusion criteria such as having at least two years of work experience and having at least an associate's degree in related fields. Sampling was continued until information saturation was reached, with a total of 10 interviews. The sample in the faculty section included eight faculty members of Allameh Tabatabai University, Shiraz University, Shahid Beheshti University, and the University of social welfare and Rehabilitation Sciences in the field of preschool education who were selected by snowball sampling method. Semi-structured interviews were used to collect data. The length of the interviews was between 27 and 90 minutes.
They were digitally recorded with the informed consent of the participants. After collecting the required data, Colaizzi's method (28) was used to perform the data analysis process. For this purpose, the text of the interviews was carefully studied to understand the feelings and experiences of the participants, and meaningful and relevant information related to the research topic was recorded in code. The codes, which were conceptually similar to each other, were categorized and named for each category. Then, by merging different classes based on common concepts, more general categories were created in the form of main and sub-themes. Finally, validation was performed by referring to each sample and asking about the findings. The validity of qualitative data using four judgment criteria of Lincoln and Guba and reliability of qualitative data through test-retest reliability (validity index) and intercoder agreement (intra-subject agreement) has been confirmed.

\section{Results}

After analyzing and classifying the data and completing the coding step, about 217 initial codes were primarily extracted. After deleting and merging some of them, the number of codes was reduced to 139 . These initial codes were categorized into 22 sub-themes and six main themes, which are:

The Main theme 1: Individual characteristics: Individual characteristics refer to the components that influence the characteristics of the educator as a role model for children and his ability to better perform his role. This was the most important topic of the research that the educators mentioned many times in their interviews, which includes 24 basic codes and three sub-themes of the personality characteristics, wellgroomed, and educator's speaking.

The main theme 2: positive emotional climate: Emotional climate reflects the emotional connection between the educator and the child, intimacy, respect, and enjoyment, which includes 31 basic codes and five sub-themes of eye contact, verbal and non-verbal affection, positive emotions, and behaviors, respect for the child and active listening.

The main theme 3: supportiveness: It involves the educator's sensitivity and responsiveness to children's emotional needs, which facilitates exploration, comfort, and reassurance. This theme includes 28 primary codes and four sub-themes of responding, encouragement, and affirmation of the child, giving children the right to choose and delegate responsibility. The main theme 4: learning opportunities: Includes the educator's use of educational activities and programs to enhance the quality of interactions and enhance higher-level thinking skills in children, creativity at work, and the provision of feedback that encourages children to learn and engage in activities. This theme includes 26 basic codes and four subthemes of teaching-learning patterns, facilitation, and preparation, creativity at work and quality of feedback.

The main theme 5: group participation: Includes the role of the educator in creating a team spirit, expanding interactions with children, and sharing various daily experiences with the child. This theme includes 14 basic codes and three sub-themes of 
educators' involving at the activities, group activities, and peer interaction.

The main theme 6: behavior management: Includes the ability and quality of the coach's action in the redirection of misbehavior and using appropriate strategies to prevent misconduct. This theme includes 16 primary codes and three sub-themes of setting clear behavioral expectations, the direction of the misconduct, and justice and nondiscrimination.

\section{Conclusion}

The results showed that the quality of the child-educator interaction process falls within six main themes. The first theme was individual characteristics. Because children are easily affected by educational environments, the characteristics of the educator can lead to better fulfillment of the goals of the education system. This finding is consistent with Zarei's (21) research. The second theme was the positive emotional climate. Kindergarten is the second most important place after home where children spend considerable time in and its prevailing situation affects children's personality. This finding is consistent with those of prior studies $(29,13,12)$. The third theme was supportiveness, which shows the educator's sensitivity and responsiveness to children's needs. This finding is consistent with the research of Layzer and Goodson (22). The fourth theme was learning opportunities. By using quality educational models and providing appropriate feedback, educators involve children both passively and actively in the learning experience. This finding is consistent with Yair's research (15). The fifth theme was group participation. Findings showed that providing a platform for group activities and the presence of an educator in the activities is an important factor in the quality of interaction. This finding is consistent with Stroet's research (14). Finally, the sixth theme was behavior management, which is in line with research by Diaz (18) and Sutherland (19), which showed that educators can provide growth and learning by setting clear behavioral expectations and predicting problem behaviors. In conclusion, it can be argued that the early years of childhood are very important in relation to the development of basic skills and the formation of children's personalities.

One of the limitations of this research was choosing the educators for the age group of four to six years as the research sample. Additionally ,this study, like all other qualitative studies, was not far from the bias and personal analysis of researchers. However, separate coding and coding synchronization sessions may have helped solve this problem to some extent. Thus, in future research, studies in other age groups, as well as the development of quality assessment tools for child-educator interaction based on the research findings, are suggested. Therefore, we suggest that future researchers investigate other age groups and also develop a tool to measure the quality of child-educator interaction based on research findings.

\section{Ethical Considerations}

Compliance with ethical guidelines: This research has been extracted from the doctoral dissertation of the first author, in the Islamic Azad University, Science and Research Branch of Tehran, on 2020/1/27, with ethics IR.IAU.SRB.REC.1400.113. its implementation license has been issued by the Welfare Organization of the country with the letter number 142708/99/900 and the Welfare Organization of Tehran province with the letter number 57187/993/717. In this research, the ethical codes like obtaining the informed consent of the participants and confidentiality were considered by the authors.

Funding: The present study has conducted without any sponsoring from a specific organization.

Authors' contribution: This article is part of the first author's doctoral dissertation under the supervision of the second and third authors and the advice of the fourth author.

Conflict of interest: There is no conflict of interest for the authors in this study.

Acknowledgments: The authors consider it necessary to appreciate dear professors, principals, and educators of kindergartens. 


\section{واكاوى و شناسايى مؤلفههاى كيفيت فرايند تعامل مربى-كود ك: بزوهش كيفى}

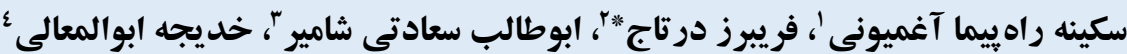

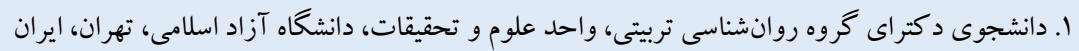

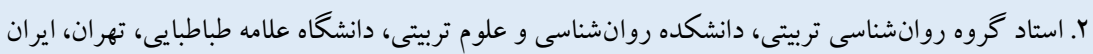

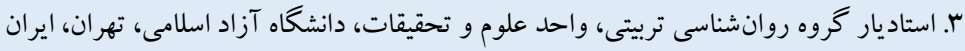

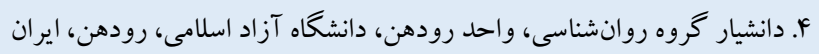

\section{جكيده}

زمينه و هدف: كيفيت فرايند تعامل بين كودك و مربى، با توجه به حسـسـيت، سهولت اثريذيرى، بايدارى و عمق ياد گيرى كود كان در

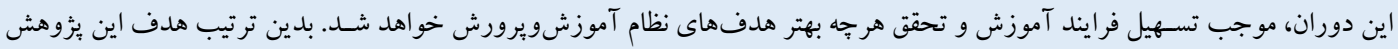
واكاوى و شناسايى مؤلفهاى كيفيت فرايند تعامل مربى و كود كك در مهدهاى كودك شهر تهر ان بود.

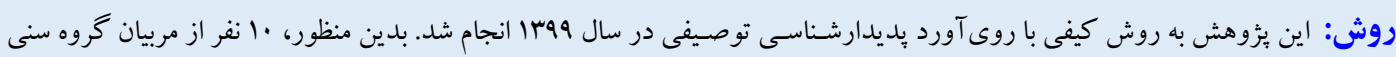

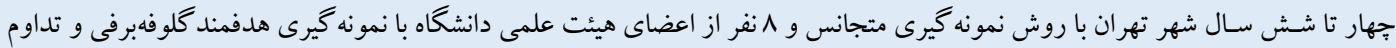

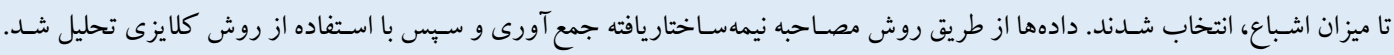

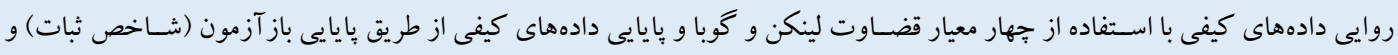

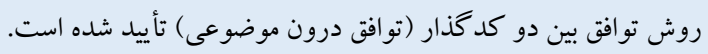

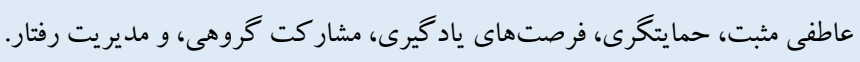

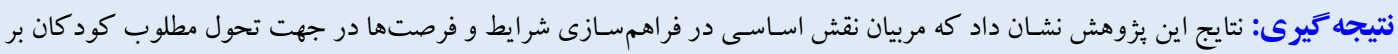

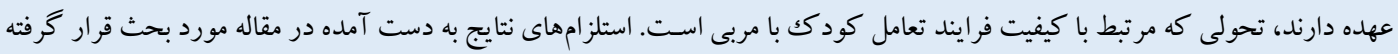


از ذهن، شـخصيت، و مهارت هاى كود كى در ينج سـال نخست زندكى

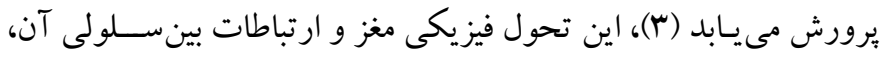

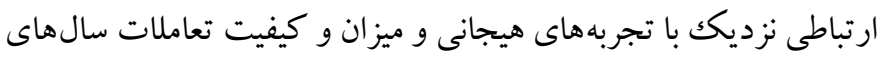

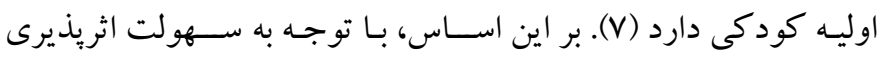

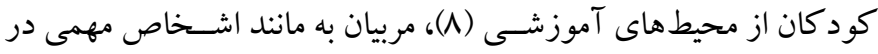

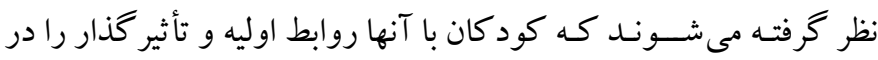
تعاملات روزانهشان برقرار مى كنند (q).

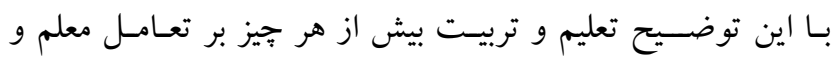

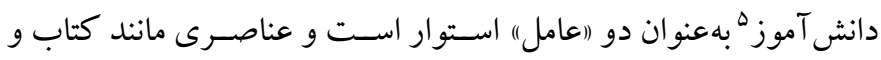

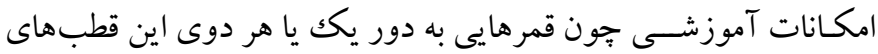

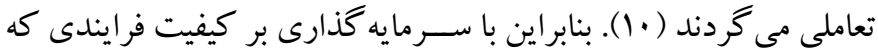

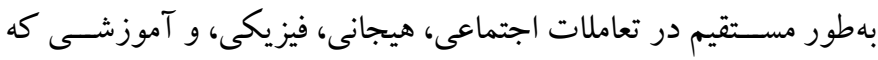

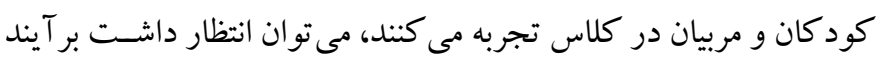

(كود كان) هم از كيفيت مطلوبى برخوردار باشند (ه). با مرور يزوهش هايى كه در اين موضسـوع، ماهيت مؤلفههاى كيفيت

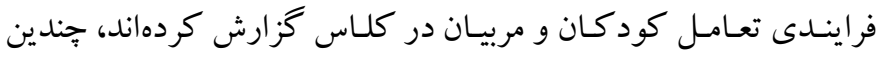
مؤلفـه مهم از جمله صــبورى و انعطاف يذيرى مربيان در كار با كود كان

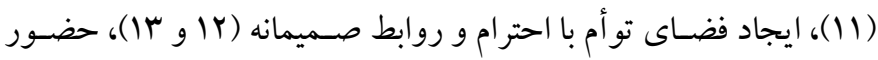
مربى در بـازى و فعـاليـتهـاى كودكـان (F) (|)، برنـامـهريزى فعـاليتهاى

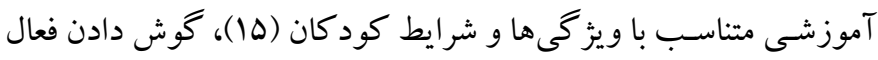
(به نقل از 19)، ارائه بازخوردهاى مناسـب (IV) و اسـتفاده از روشهاى راهنمايى مثبت در مو اجهه با رفتار هاى نادرست (1) و و 19) تأكيد داشتند.

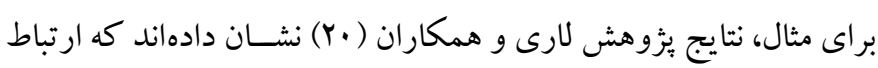

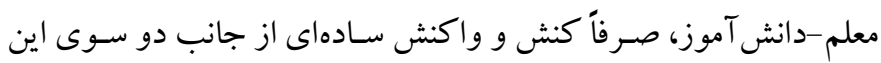
رابطه نيسـت، كه تبادل كاملى اسـت و در بسـترى از عوامل مؤثر بر آن

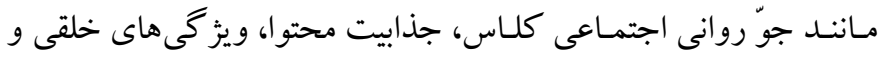

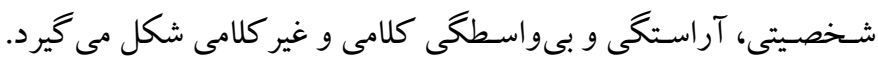

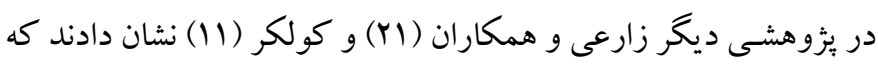

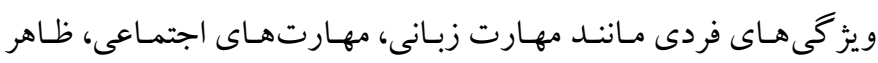

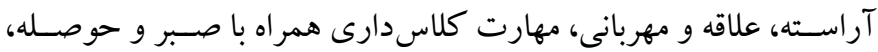

4. Two dimensions of quality process and structure 5. Teacher-student interaction
مقلهم

كودكى، مهممترين و شـــاخص ترين دوره زنســى آدمى براى تحول

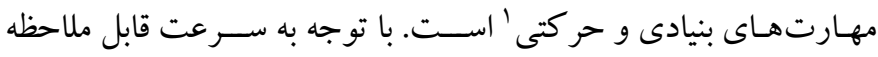

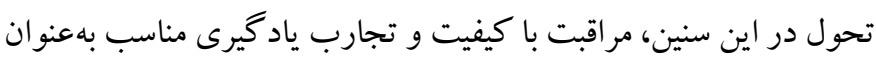

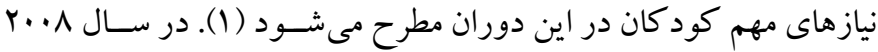

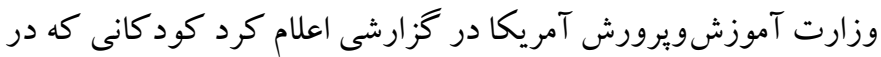

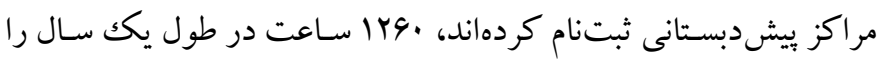

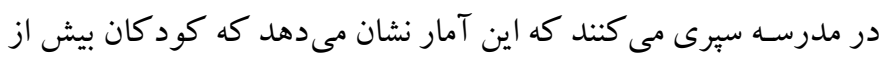

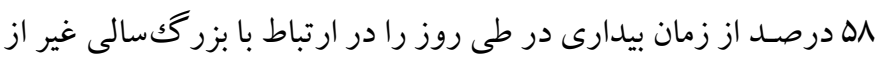

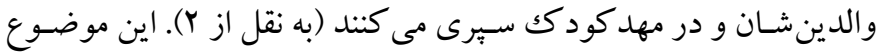

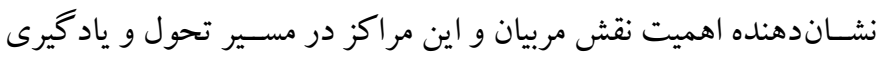

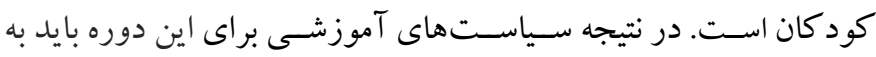

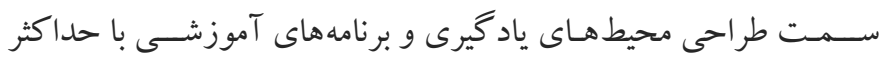

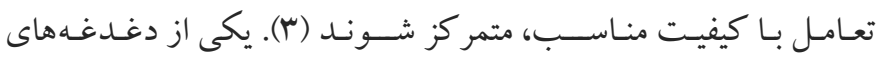

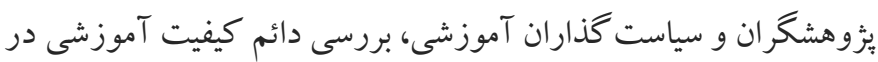

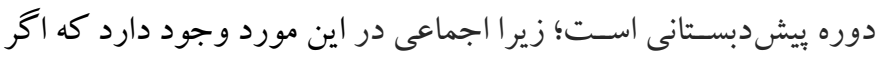

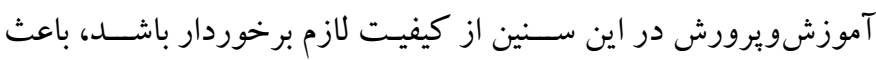

بهبود عملكرد كود كان در سالهاى بعد خو اهد شد (F).

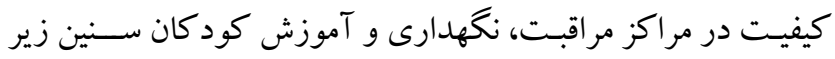

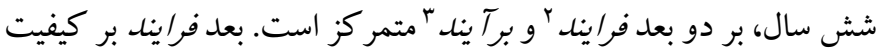

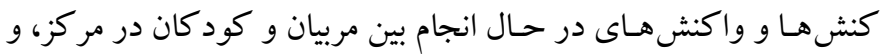

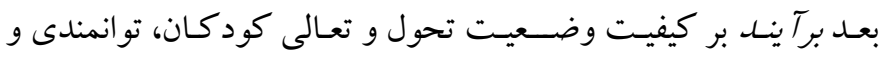

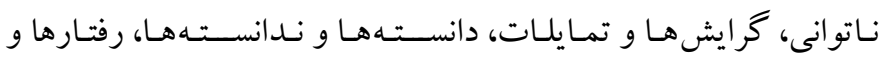
روى آوردهـاى آنها تمركز دارد (ه). اســـينوزا نيز در ارتبـاط بـا ميزان كيفيت برنامههاى بيشدبستانى به دو بعد كيفيت فرايند و سـاختار اشاره

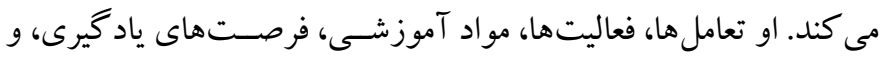

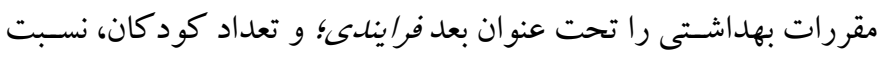

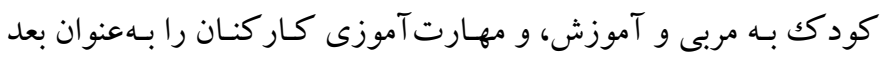

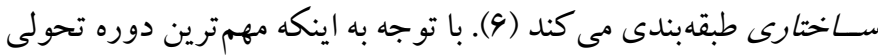

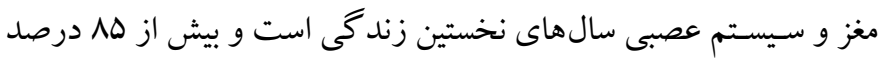

1. Fundamental \& movement skills

2. Process

3. Outcome 
روش الف) طرح يزوهش و شر كت كنند كان: اين ئزوهش به لحاظ هدف از

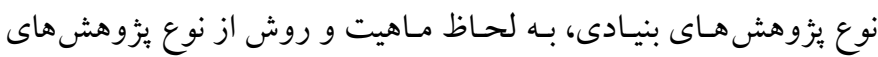

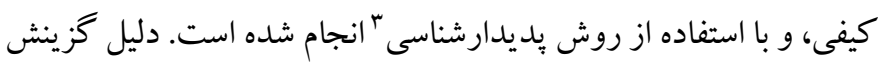

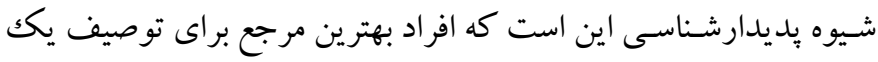

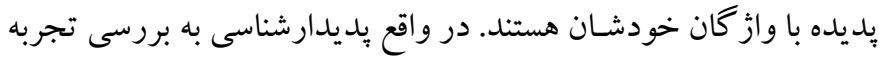

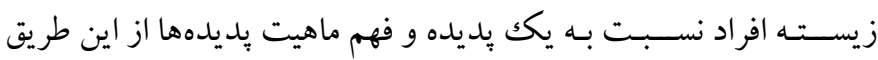

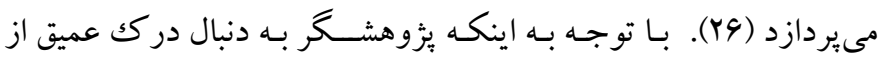

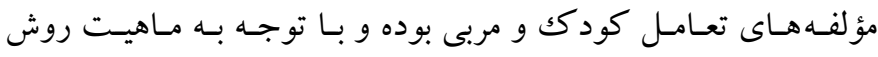
يديدارشــناسـى، در اين بررسـى از شـيوه يزوهش كيفى با روش تحليل

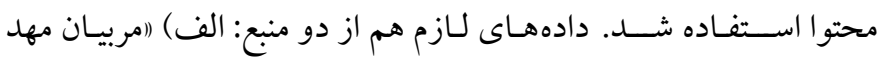
كود كك") و ب) (اعضاى هيئت علمى" به دست آمد.

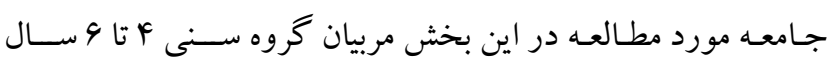

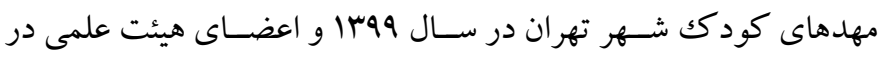
رشـته آموزشويرورش ييش از دبستان و روانشناسى و همجنين فعال در حوزه آموزشويرورش كودكك بود. انتخـاب نمونهها در جامعه انسـانى،

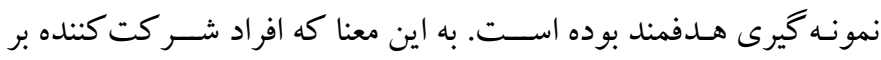
اساس قضاوت مبتنى بر مربوط بودن به اهداف يُزوهش انتخاب شدهاند و

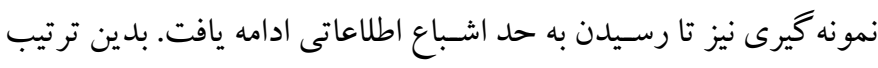

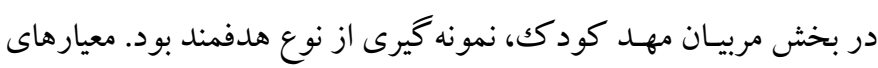

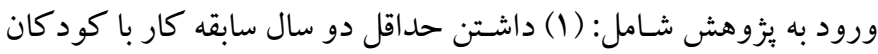

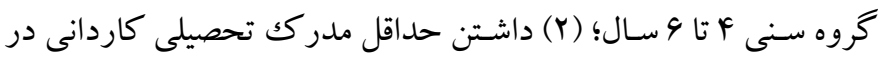

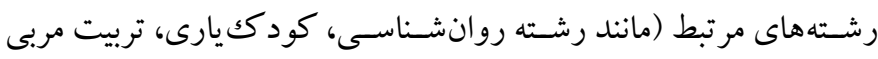

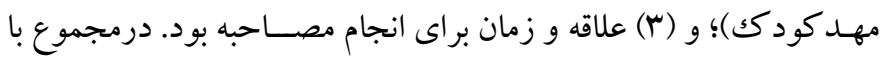
• ا نفر در محل كارشـان (مهد كودك)) مصـاحبه نيمهسـاختاريافته انجام

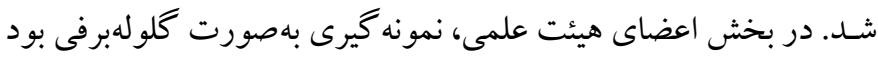

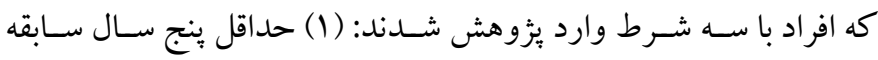
تدريس در گروه آموزشويرورش بيش از دبستان را داشته باشند، (Y) در

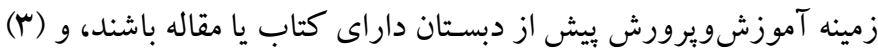

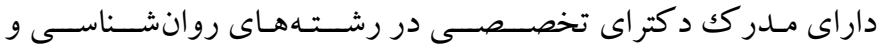

3. Phenomenology
اعتمـاد به خود و احسـاس مســوليت، انعطاف يذيرى، مهارت حر كتى، خوشخلقى و خوش برخورد بودن تـأثير زيـادى در كيفيـت تعـاملـات و جذب كود كان به آنها دارند.

يافته هاى بزوهش لايزر و گودسـان نشـان دادند كه توانايى تشـخيص

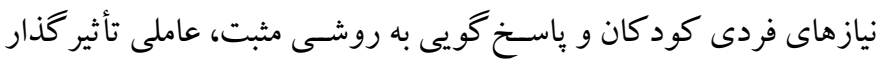
در كيفيت كلى آموزش سـالهاى اوليه كودكى به شــمار مىرود (Yr). حمـايت عاطفى'، از ديخر مؤلفههاى كيفيت فرايندى اسـت كه شــامل

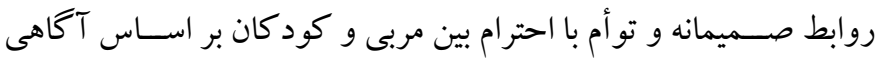

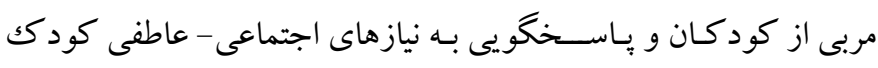

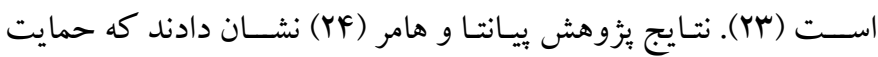
عاطفى از طريق روابط صميمانه با كود كان، باسخ گو بودن، احترام متقابل و حمايت از استقلال كود كك سبب كيفيت تعامل كودك و و مربى است.

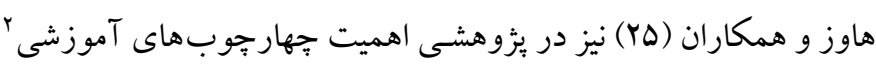

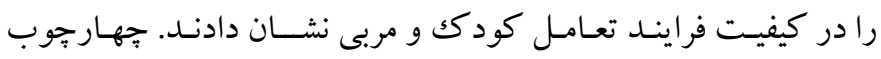

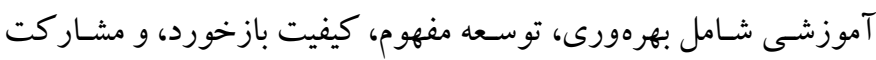

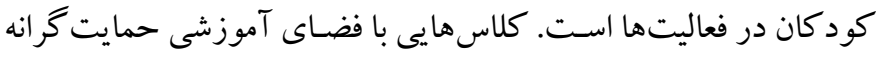
مكانهاى شـلوغى هسـتند كه با حضـور مربى و كود كانى كه فعالانه در فعاليت ها مشار كت مى كنند، بهطور هدفمند ايجاد مى هوند. مبتنى بر شـــواهد مطرح شـــه، كيفيت تعامل بين مربى و كودكك را مى توان جزئى ضـرورى از تجربه كلاس درس براى تمام كود كان و منبع

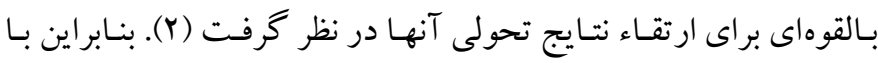

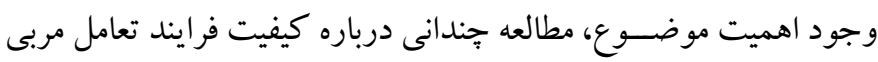

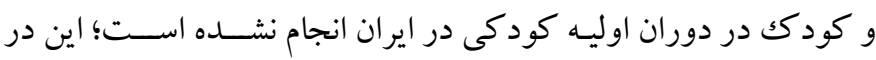

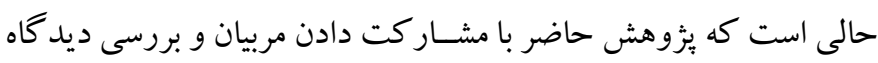

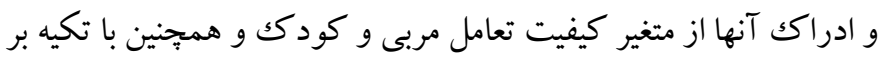
فلسفه يُزوهشهاى كيفى براى توصـيف عميق موضوع به دنبال آن است

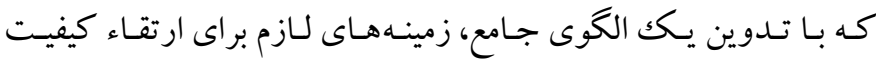

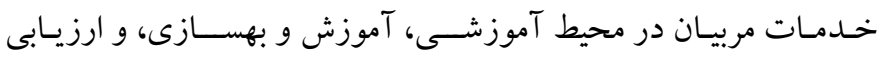

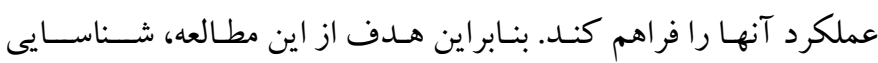
مؤلفه هاى كيفيت فرايند تعامل كود ك- مربى است.

1. Emotional support

2. Instructional frameworks 
فرايند تحليل دادهها از روش تحليل محتوا استفاده شد. روشهاى مختلفى براى تحليل محتوا وجود دارد كه در اين يزوهش از روش هفت مرحلهاى

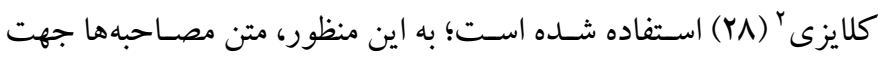
درك احســاس و تجـارب شـــركت كنند گان به دقت مطالعه و اطلاعات بامعناو ومر تبط با موضسوع يزوهش بهصورت كد يادداشـت شد. كدهايى

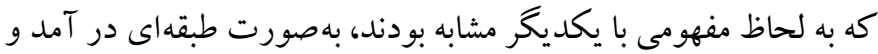

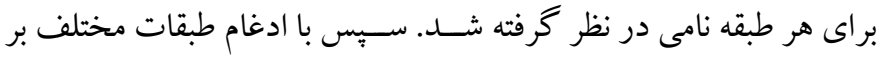
اسـاس مفاهيم مشتر كك، دستهاى كلىترى ايجاد شد و در نهايت، نتايج

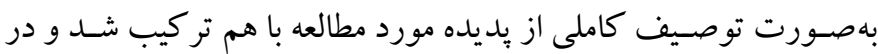
قالب مضمونهاى اصلى و فرعى سازماندهى شد. در پايان، اعتباربخشى"

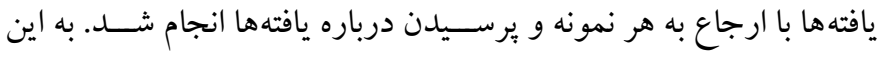

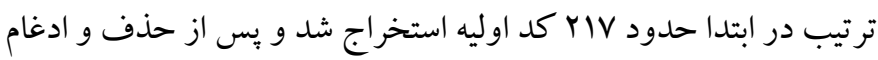

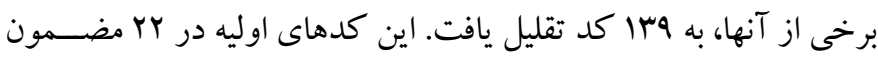

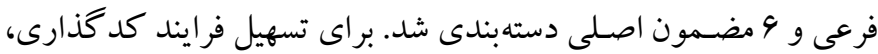
از نسخه • r نرمافزار مكس كيودا ع استفاده شد.

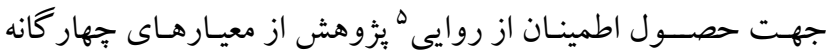
لينكن و گوبا (Yq) اسـتفاده و اقدامات زير انجام شــد: (1) قابليت اعتبار":

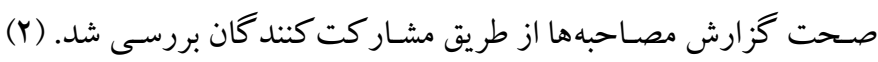

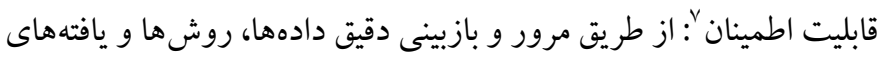

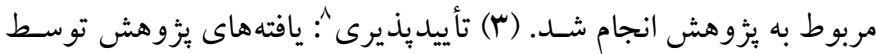

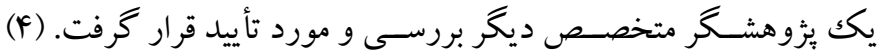

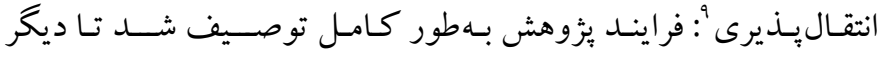

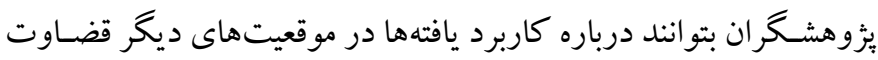
كنتـد. همجنين جهت بررسـى اعتبار " دادههاى كيفى، از روش بايايى

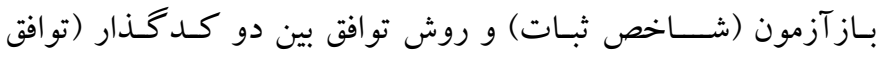
درونموضسوعى) استفاده شد كه به ترتيب VN/ • و • • به دست آمد اين شاخص و در هر دو مورد تأييد شد.

6. Credibility

7. Consistency or dependability

8. Confirmability

9. Transferability

10. Reliability
آموزشويرورش ييش از دبسـتان باشـــد. در مجموع با م نفر از اسـتادان دانشگاه علامه طباطبايى، دانشگاه شيراز، دانشگاه شهيد بهشتى، و دانشگاه علوم توانبخشى و سلامت اجتماعى مصاحبه انجام شد.

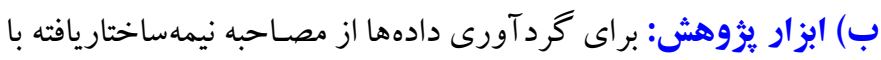

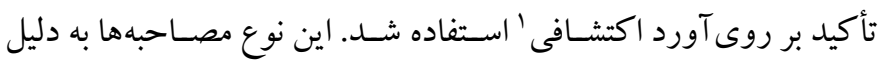

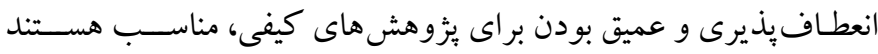
(YV) تنظيم و روايى صورى آن مورد بررسى و تأييد قرار گرفت و با استخراج سؤال هاى متناسب با اهداف يزوهش، فرم نهايى مصاحبه نيمه ساختاريافته تدوين شـــ. ســبس مصـاحبهها با ســوالهاى كلى درباره تعامل مربى با

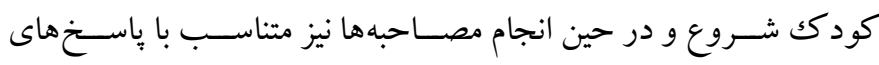
مصاحبهشـوند گان سعى شـد با طرح سؤ ال هاى موشكافانه مانند: (اممكن

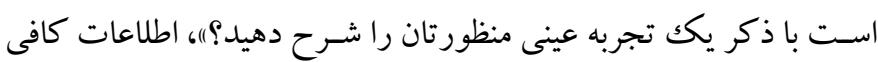

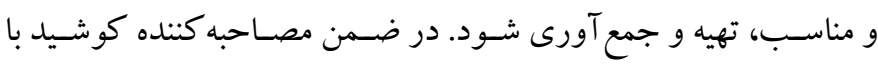
اسـتفاده از روش توجه بدون قضـاوت در طى مصاحبهها، از جهت بدهى و و

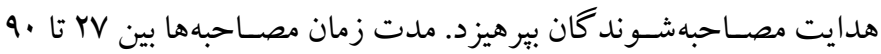
دقيقه با ميانكين fF دقيقه بود كه با رضـايت آكاهانه مشـار كت كنند كان، مصاحبه ها بهصورت ديبجيتالى ضبط شدند.

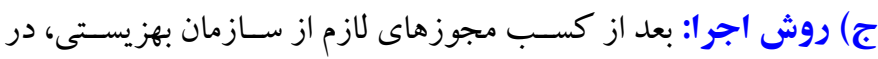
مرحله نخسـت براى انجام مصـاحبه ها بهصسورت حضسورى به مهدهاى

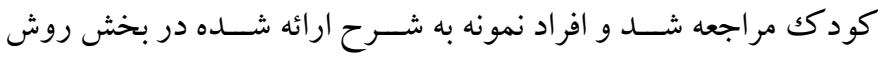

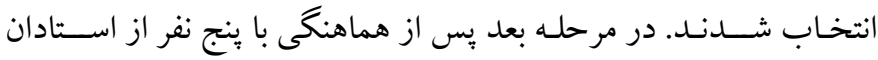

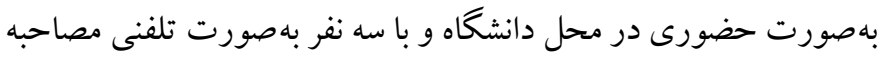

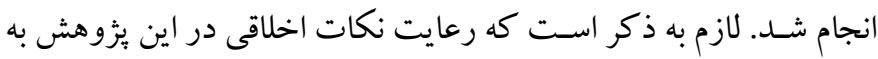

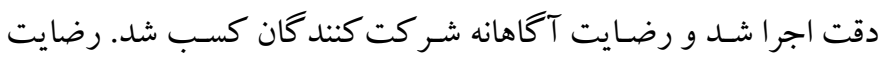

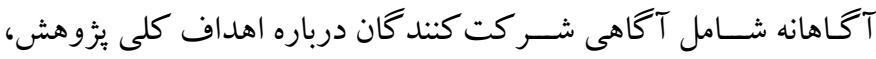
رازدارى، حريم خصـوصسى شـر كت كنند كان، حق خروج از بيزوهش و و

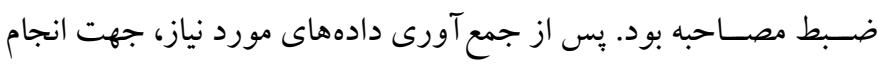

1. Exploratory approach

2. Colaizzi's seven step method

3. Accreditation

4. MAXQDA

5. Validity 
يافتهها

در اين بخش يافته هاى حاصـل از تحليل كيفى دادهها، با يكديخر مقايسـه

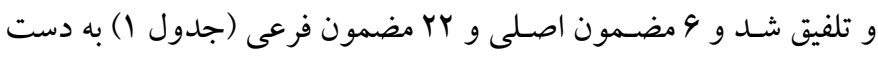
آمد كه در ادامه ارائه شدهاند.

جدول ا: مضامين اصلى و مضامين فرعى مؤلفه كيفيت فرايند تعامل مربى و كودكى

\begin{tabular}{|c|c|c|c|}
\hline مضامين فرعى & مضامين اصلى & مضامين فرعى & مضامين اصلى \\
\hline الخوهاى ياددهى-ياد گيرى & فرصتهاى ياد گيرى & 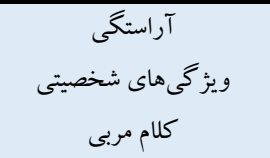 & ويز گیىهاى فردى \\
\hline 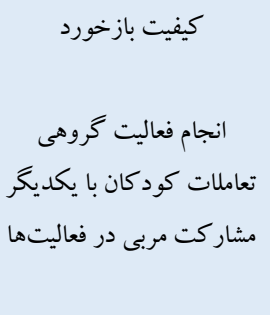 & مشار كت گروهى & 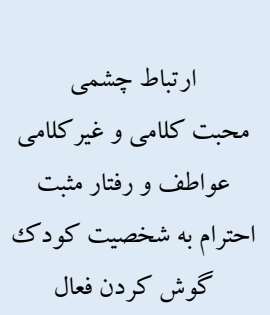 & فضاى عاطفى مثبت \\
\hline هدايت رفتار التار نادرست روشن رفتارى & مديريت رفتار & 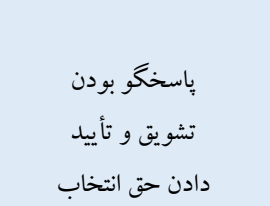 & حمايت گرى \\
\hline & واكذارى مسئوليت & & \\
\hline
\end{tabular}

مضمون فرعى ץ) ويز گى هاى شخصيتى: اين مضمون دربردارنده ده

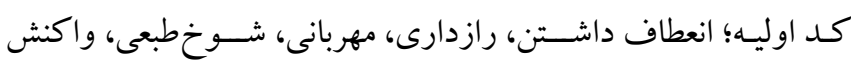

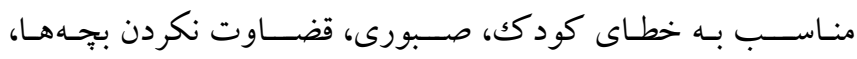
خوشرويى، قاطعيت در رفتار، و مهار هيجانات است.

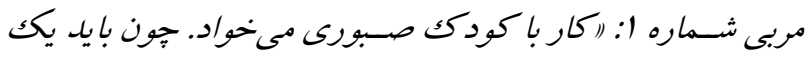
موضوع را درقالب هاى مختلف Tموزش بلدهد؛ يعنى شعرش را بكويد، بازيش را بكند و قصه/ش را بكويد. /ين نياز به تكرار داردها.

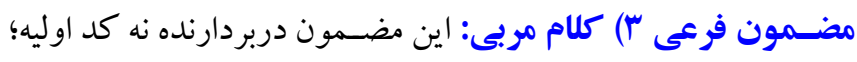

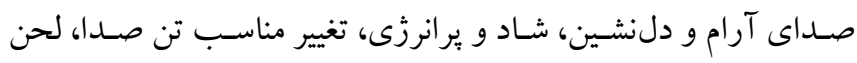

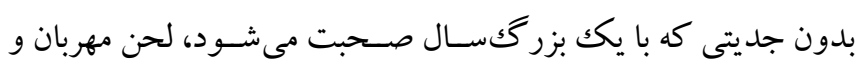

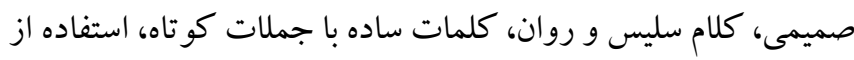

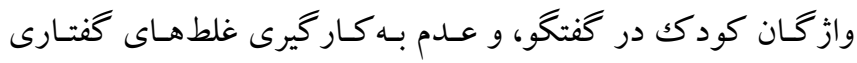
كودك در كفتخو است.

\section{مضمون اصلى ا: ويزّكى هاى فردى}

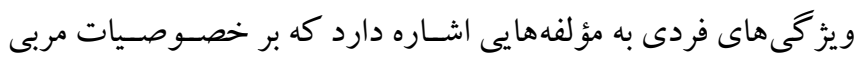

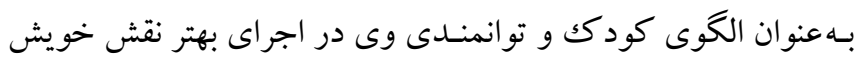

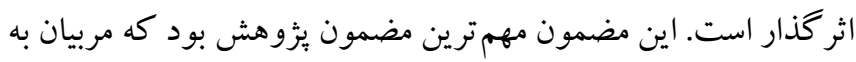

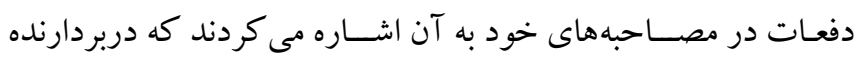

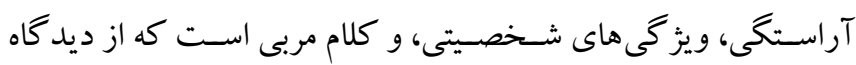
مربيان نقش مهمى در تعامل با كودكى دارد. مضـمون فرعى () آراستكى: اين مضسمون دربردارنده ينج كد اوليه؛

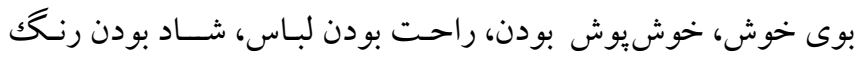
لباس، و يوشش تميز است. مربى شــماره ץ: اكودك ارتباط را /ول /ز ظطاهر مربى دريافت

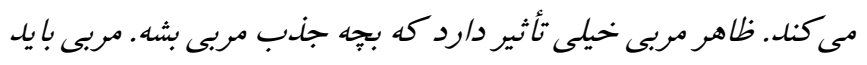

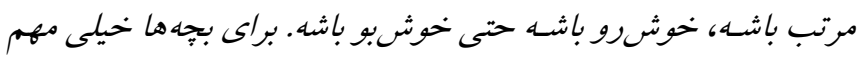
است كه مربى لباس تميز و شاد به تن د/شته باشلد). 
مضــمون فرعى ع) احتر ام به شــخصـيت كودك: اين مضــمون دربردارنده نه كد اوليه؛ سـلام و احواليرسى كرم هنكام ورود كود كك، خطاب كود كك با ضسمير شما، خطاب كودكك با صفات زيبا يا لفظ آقا

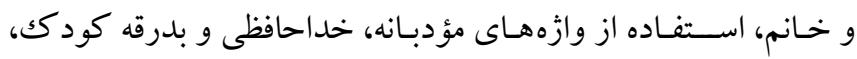

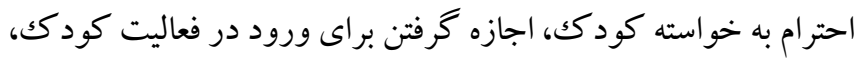

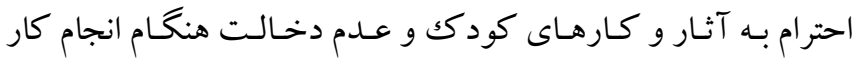
توسط كودك است.

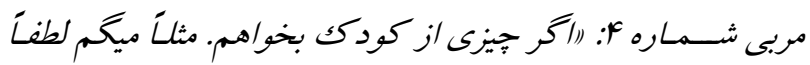

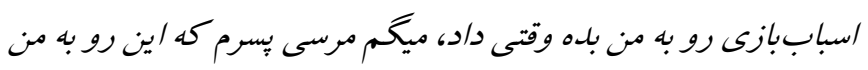
دادى. دفعه بعد /و هم /ز من تشكر مى كنهاه).

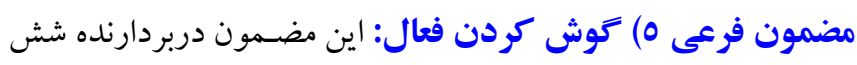

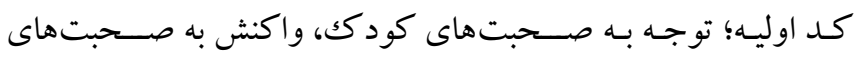

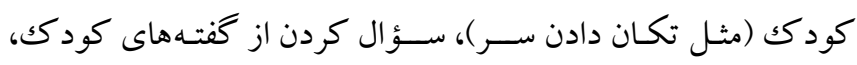
انعكاس كفته هاى كودك، انعكاس احسـاسات كودك، و قطع نكردن صحبت كودك است. مربع شـماره V. إبا يل بهدقت به صحست هاى كودكى كوش كرد و

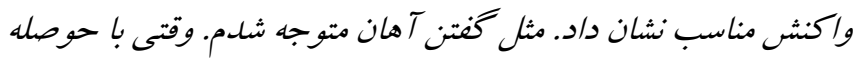

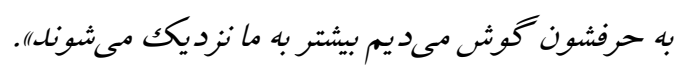
مضمون اصلى "َ: حمايت كرى

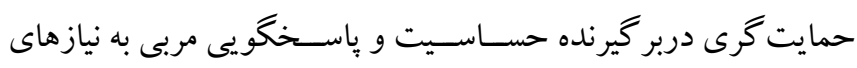
عاطفى كود كان است كه موجب تسهيل كاوشخرى، آسايش و اطمينان

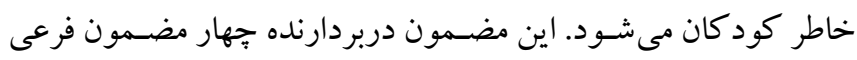

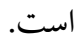

مضمون فرعى 1) ياسخ كو بودن: اين مضـمون دربردارنده يازده كد

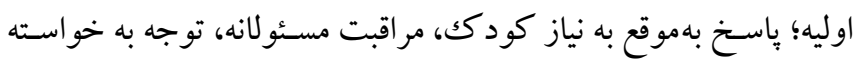
كودك، حسـاس بودن به نيازهاى فيزيولوزيكك كودك (مثل تغذيه و

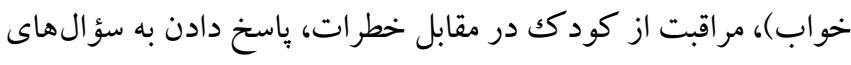
كودكان، درك و بذيرش احساسات كودك،، تشويق كود كان به ابراز احسـاســات، فراهم كردن زمينه آرامش كود كك، درك مع معناى بنهان حرف كودك، و نگاه به دنيا از دريجه نغاه كود كك است.

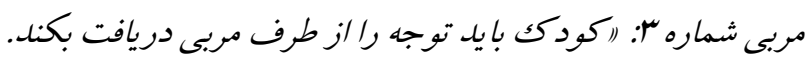

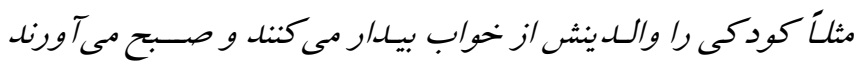

كارشسناس شـماره ا: ادر محتواى كلام هم نبايد غلطهاى كودك

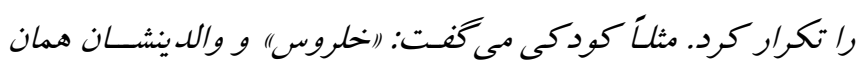

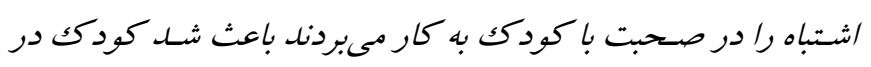
بزرك سالى نيز به خروس، خلروس بكويدة).

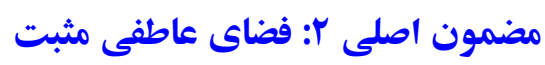
فضاى عاطفى باز تابدهنده ييوند عاطفى بين مربى و كود كان، و تبادل

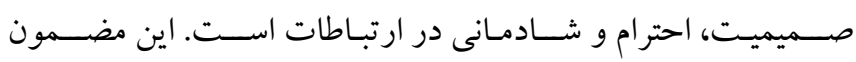
دربردارنده پِنج مضمون فرعى است.

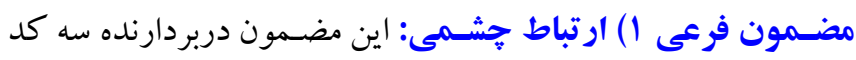
اوليه؛ در قـامـت كودكـان قرار گرفتن، حالت بدنى مربى و كود كك در مقابل يكديخر، و برقرارى ارتباط جشمى با كود كك است.

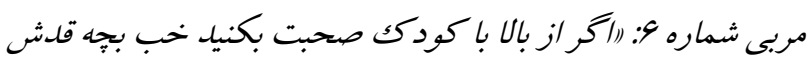

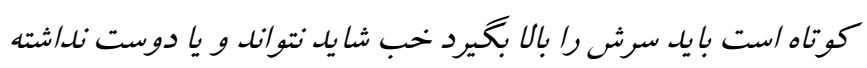

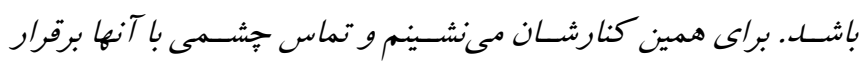

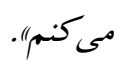
مضــمون فرعى r) محبــت غير كلـامى و كلـامى: اين مضــمون

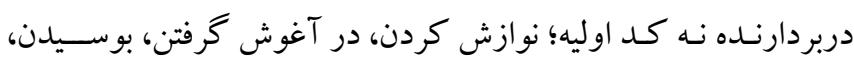

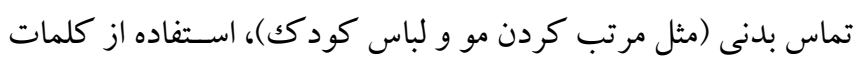
با بار معنايى دوسـت داشـتن (عزيزم)، كاربرد كلمه جان در انتهاى نام

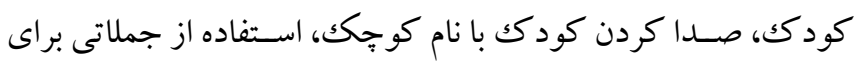

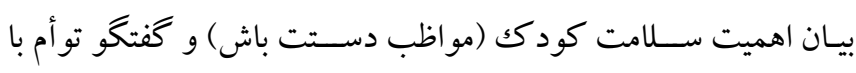
عطوفت است.

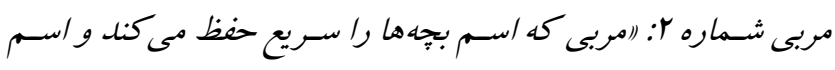

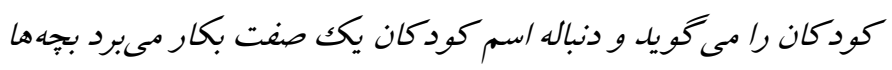
آنها را خيلى دوست دارندا".

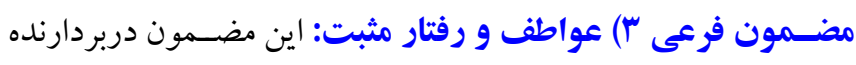

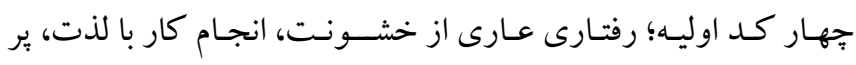
جنبوجوش و فعال بودن، و عدم استفاده از وازههاى تهديد آميزاست.

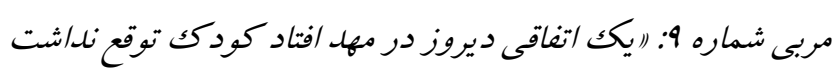

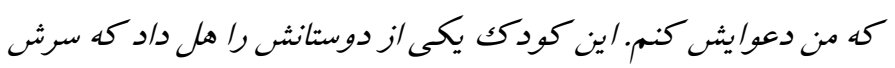

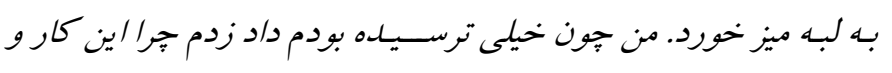
كردى؟ همين اخمى كه كردم به بِدرش كفته بودال. 
و ترغيب كود كان به انجام فعاليت مى شـود. اين مضــمون دربردارنده جهار مضمون فرعى است. مضــمون فرعى 1) الكوهـاى يـاددهى - يادكيرى: اين مضــمون دربردارنـده هشــت كـد اوليـه؛ توجـه بـه توانايى و تفاوتهاى فردى،

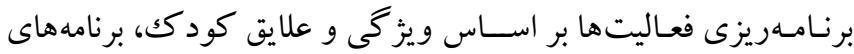

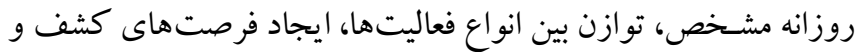

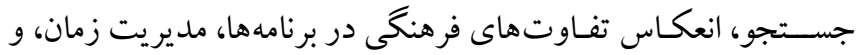

$$
\text { تنوع برنامه ها و فعاليت ها است. }
$$

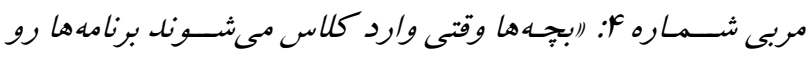

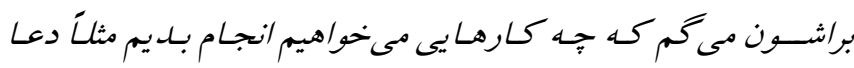

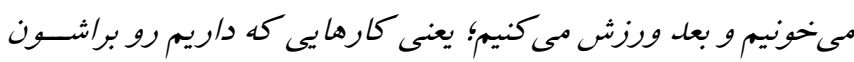
توضيح مى تمدم" مضـمون فرعى ץ) تسـهيل و آمادهسـازى: اين مضمون دربردارنده شـش كد اوليه؛ آماده كردن كلاس براى شـروع فعاليت و بازى، آماده

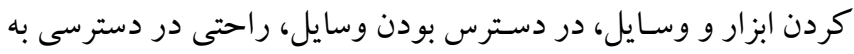

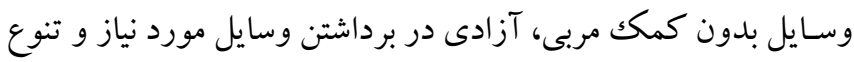

$$
\text { تجهيزات و وسايل آموزشى است. }
$$

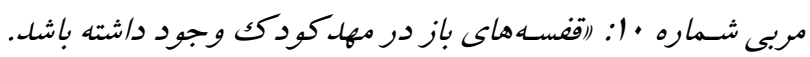

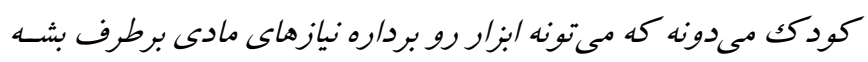

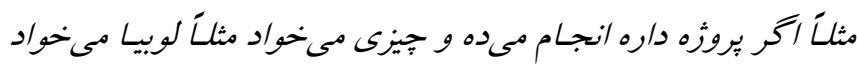

$$
\text { مى تونه بره /ز بخش آشيزخانه لوبيا برد/رد). }
$$

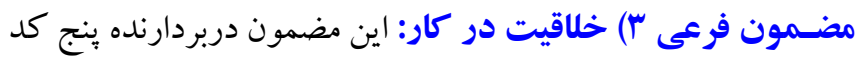

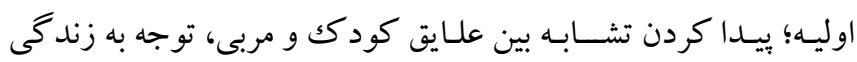

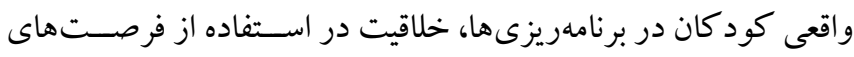
غيرمنتظره، اســفــاده از روشهـاى جـذاب و خلـاقـانه در كار و فراهم كردن محيط براى حل مسئله است.

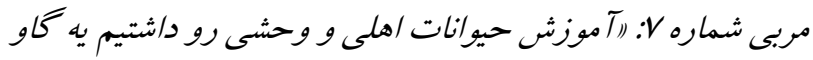

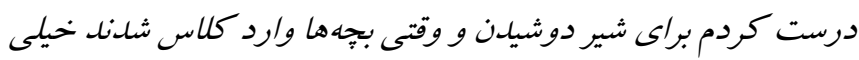
شوق و ذوق د/شتندا،. مضـمون فرعى ع) كيفيت بازخورد: اين مضـمون دربردارنده هفت

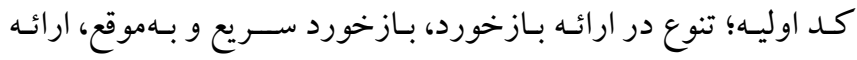

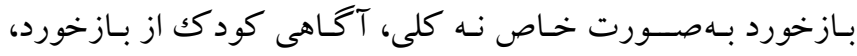

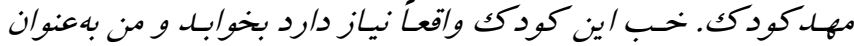
مربع با يد دركش بكنم"ا. مضـمون فرعى ץ) تشويق و تأييد كودكى: اين مضمون دربردارنده ده كد اوليه؛ تشـويق مشخص و بلافاصله، تحسين آنجه كودك به بهور واقع انجام داده اسـت (آفرين جه كاردسـتى درسـت كردى)، تحسـين

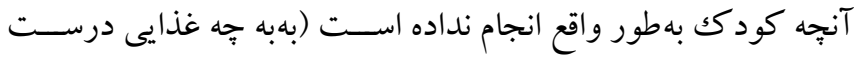

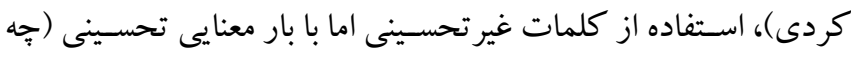

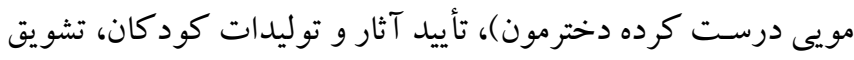
ييشـرفت و تلاش كود كك، تشـويق هيجانات مثبت، تشويق و حمايت از رفتار مثبت كودك و توجه و تأكيد بر فرايند كار است.

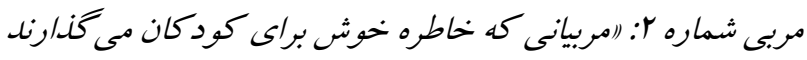

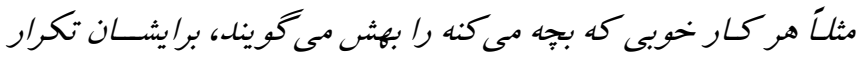

$$
\text { مى كنن، مرور مى كنن و آفرين مى كويندا، }
$$

مضمون فرعى ץ") دادن حق انتخاب: اين مضمون دربردارنده جهار

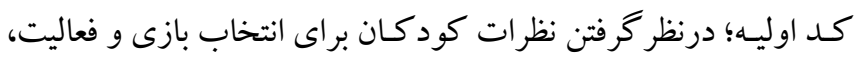
آزادى عمل كود كك در نحوه انجام فعاليت و انتخاب وســايل، انتخاب آثار توســط خود كودكك براى نمايش، و حق انتخاب كودكك از بين جند برنامه و فعاليت كلاسى است.

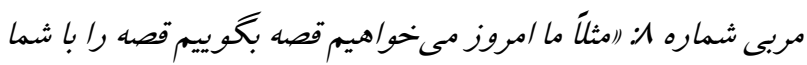

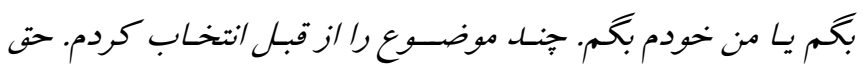
انتخاب /ز بين آنها را به كود كان مىدهم كه يكى را انتخاب كنندا). مضـمون فرعى ع) واكذارى مسئوليت: اين مضـمون دربردارنده سه

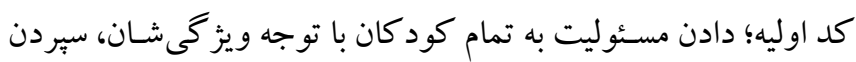
وظايف مشخص به كودك، و ايجاد حس ارزشمندى است.

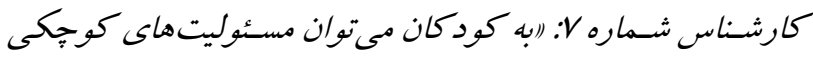

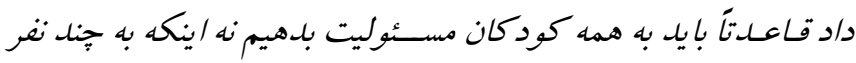

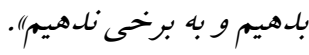

\section{مضمون اصلى ع: فرصتهاى ياد كيرى}

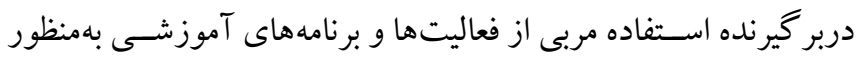
ارتقـا كيفيـت تعـاملات و تقويت مهارتهاى ســطح بالاتر انديشــهـ در كودكان، و خلاقيت در كار و ارائه بازخوردهايى كه موجب يادگيرى 
باشيم، مراقبت بكنيم در صورتى كه تعامل /ين مىشود كه ما خودمون رو

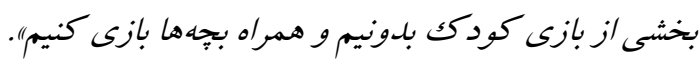
مضمون اصلى 7: مديريت رفتار

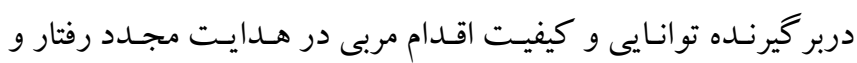

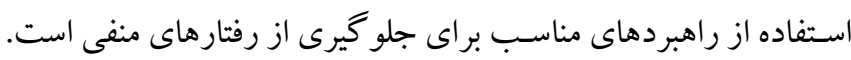
اين مضمون دربردارنده سه مضمون فرعى است. مضمون فرعى 1) انتظارات روشن رفتارى: اين مضمون دربردارنده

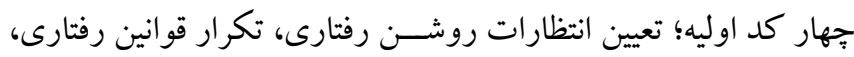

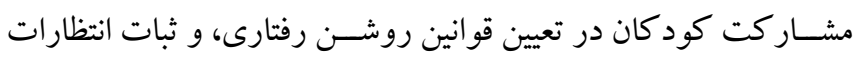

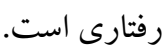

مربى شماره ث: "رعايت قوانين مهم /ست براى نمونه قبل /ز خوراكى

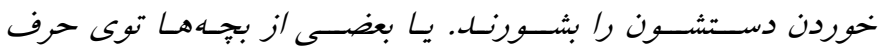

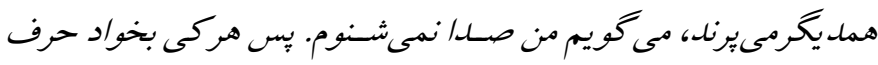
بزنه با يد دستش را بالا ببرد).

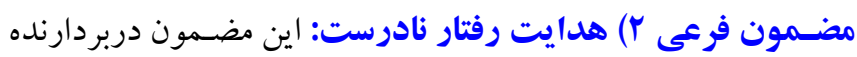

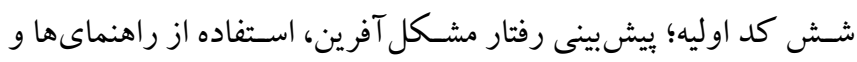

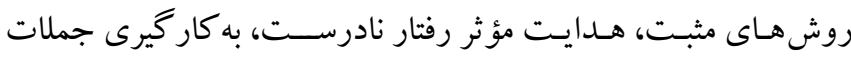

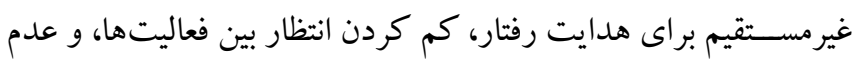
استفاده از تهلديد و تنبيه براى مهار كود كك است.

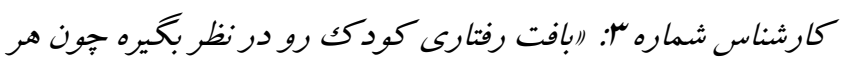

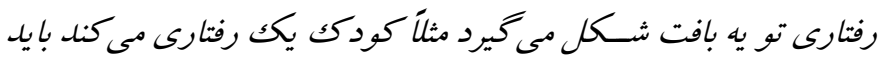

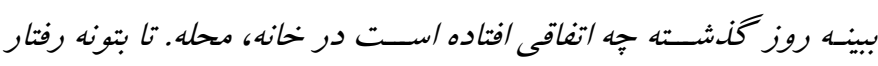
كودكك را بهدرستى تغسير نما يلها. مضـمون فرعى ץ) عدالت و عدم تبعيض: اين مضـمون دربردارنده شـش كد اوليه؛ توجه به تككتك كود كان، نگكاه به تككت تك كود كان،

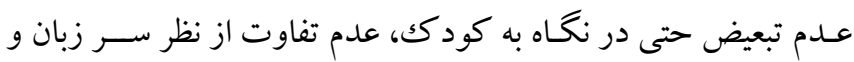
قيافه، عدم تفاوت بين دختر و بِسـر، عدم مقايسـهـ كود كان با يكديكر مربى شما ره ه: (ربين بجهها فرق نمىذارم. خوشكل بودنشان يا دختر و

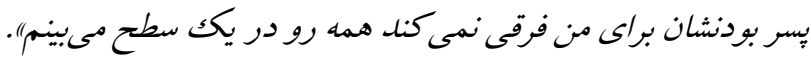

بـازخورد بـه معانى آثار كود كان، توضسيح دقيق در مورد كيفيت كار تكك تك كود كان، و گفتخوهاى رفت و بر گشتى است.

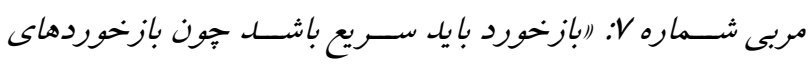

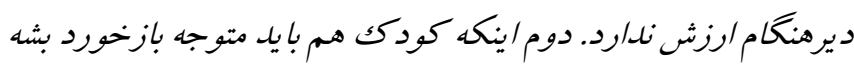

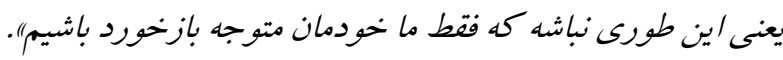
مضمون اصلى 0: مشاركت كروهى

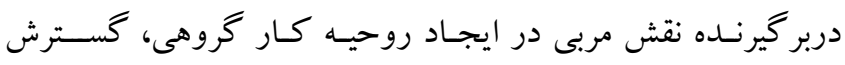

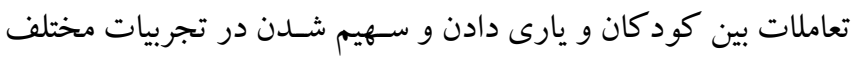

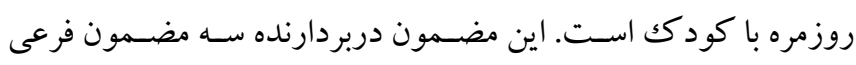
مضـمون فرعى 1) انجام فعاليت كروهى: اين مضـمون دربردارنده

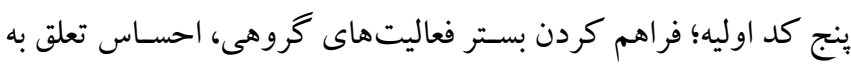

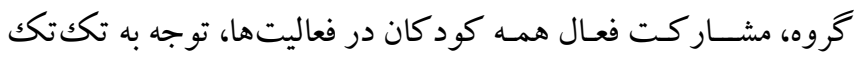
كود كان در گروه و توسعه مشار كت بهجاى رقابت است.

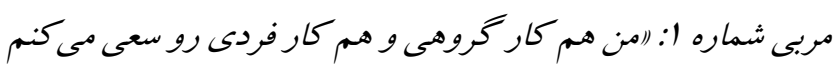
انجام بدم.كودكى كه دوست دارد همش كار فردى بكند سعى مى كنم

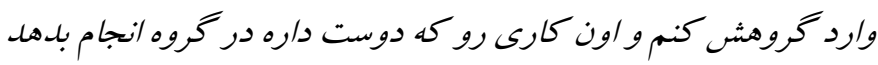

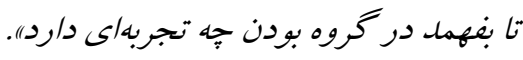
مضــمون فرعى ץ) تعـاملـات كودكـان با يكديكر: اين مضــمون

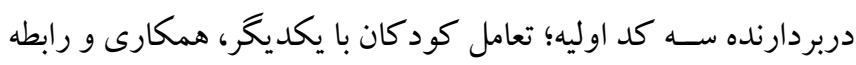
دوستانه بين كود كان و انتخاب همبازى است.

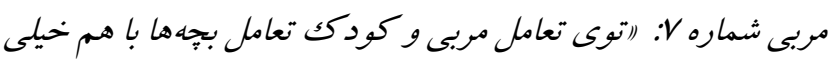

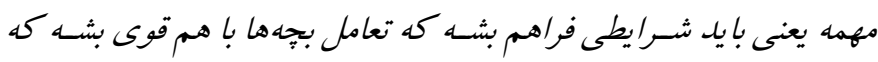

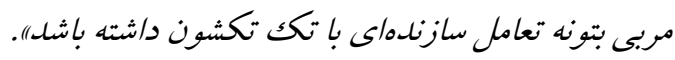

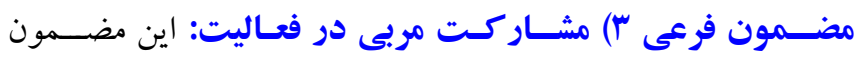

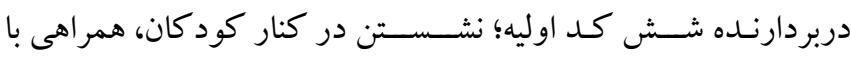
كود كى جهت انجام كارها، انجام همزمان فعاليت توسط مربى در كنار

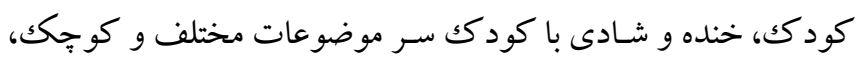

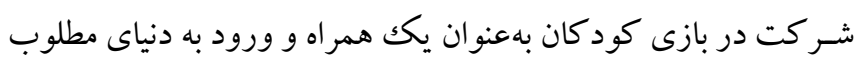

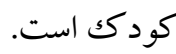

مربى شــماره r: (رازيىهاى كود كان خيلى معانى دارند. ما اكثراً فكر

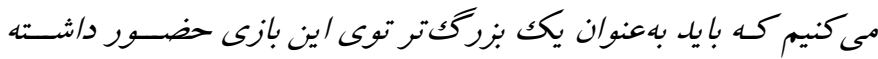


عاطفى مثبت مى شـود. فضاى عاطفى به مربى كمكك مى كند تا روابطى

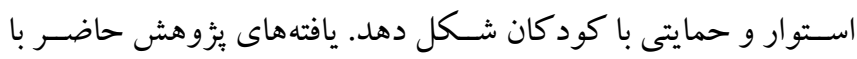

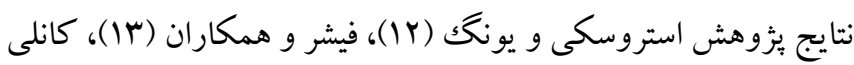

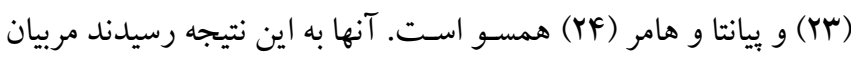

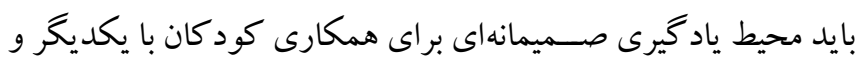

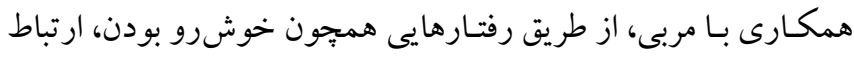

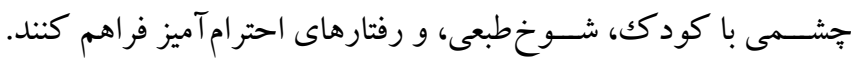

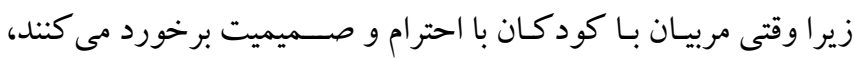
احترام و لبخندهاى بيشترى از سوى آنها دريافت مى كنند. رفتار هايشان وتئان

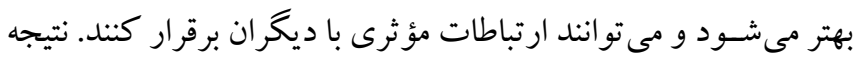

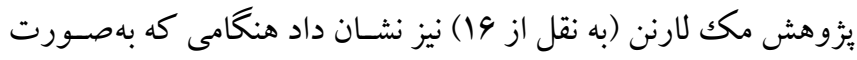

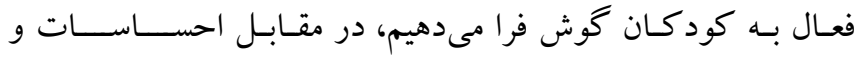

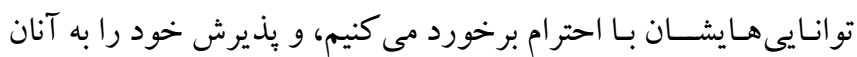

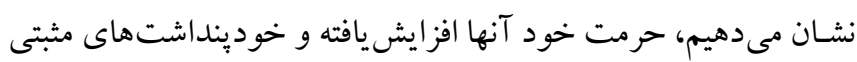
از خود خواهند داشت.

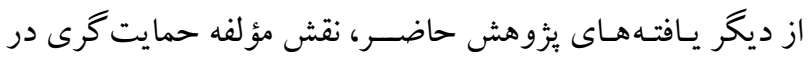

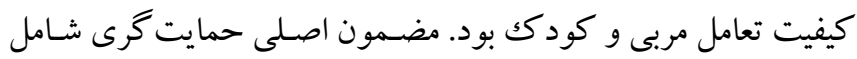

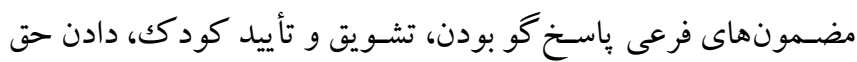

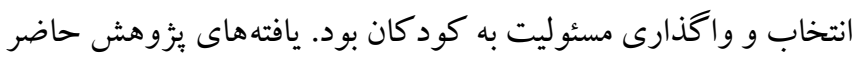

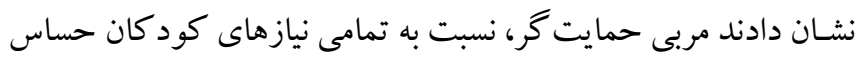

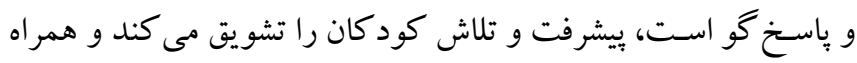

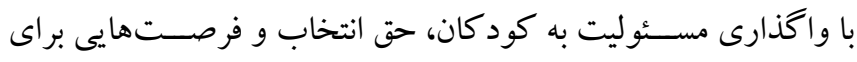
ابراز احسـاسـات، افكار، و ديد كاهها درباره تكاليف نيز فراهم مى كلى كند.

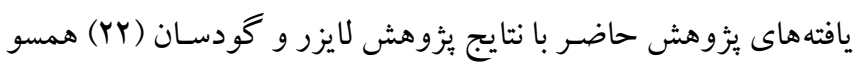
است. آنها به اين نتيجه رسيدند كه رفتار و نحوه تعامل مربى با كود كان يتان

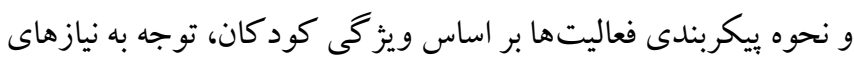

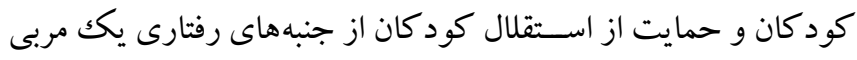
حمايت گر هســتند و از عو امل اصسلى و مهم در تجربيات كود كان به ونه

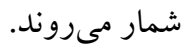

مضــمون فرصـتـهاى ياد كيرى از ديخر يافته هاى اين بزوهش بود.

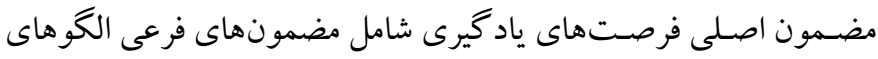

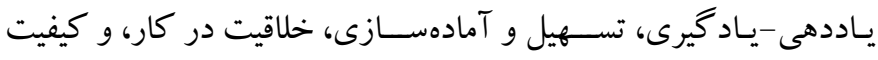

\section{بحث و نتيجه كيرى}

يزّوهش حاضـر با روى آورد بديدارشناسى به شناسايى مؤلفه هاى كيفيت

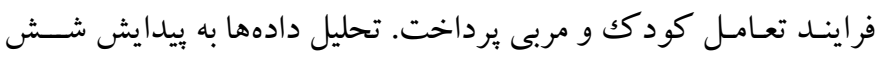

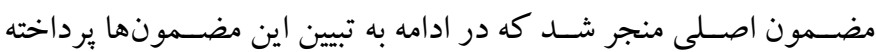
خواهد شد. از مضــامين اصسلى اين بثزوهش مى توان به ويز كى هاى فردى اشـاره

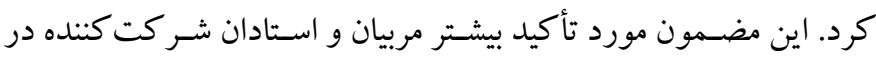

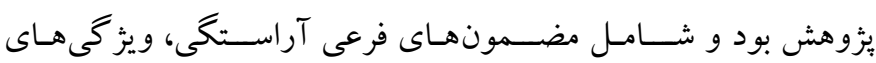

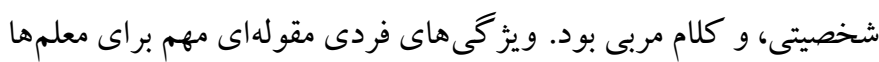

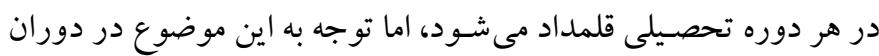

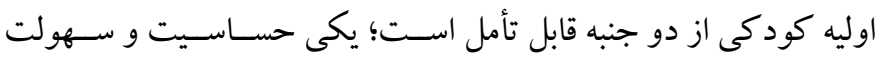

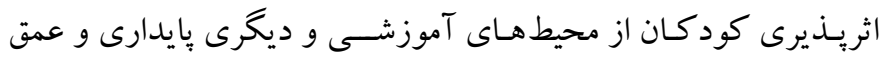

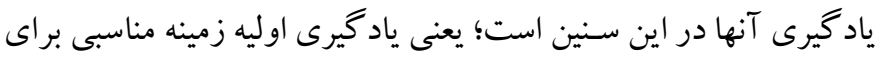

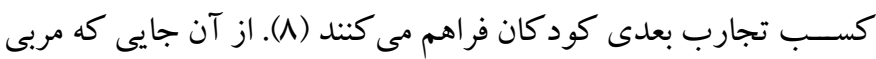
در تحقق اهـداف آموزشـى نقشـى كليـدى ايفـا مى كنـد، بـدون ترديد

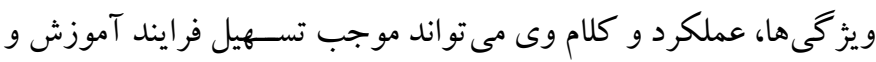

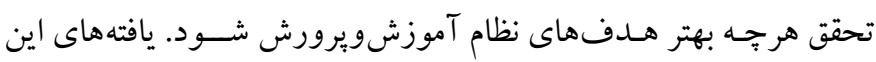

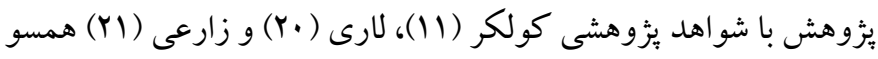

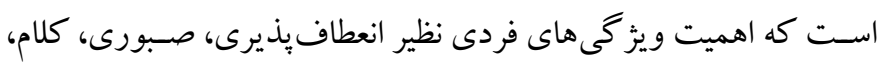

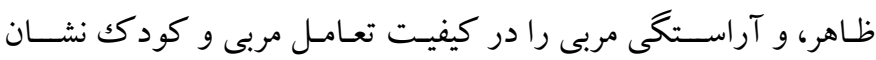

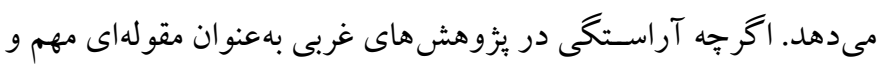

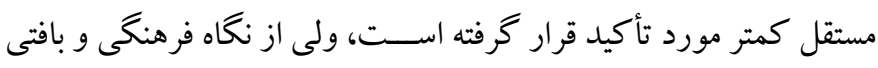
در جامعه ما به آن برداخته شده است.

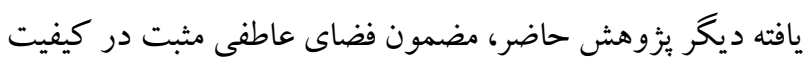

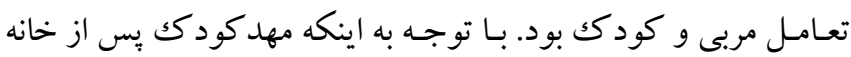

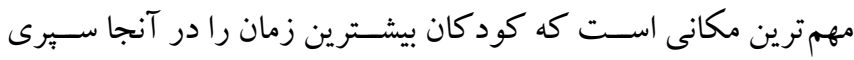
مى كنند و جوّ حاكم بر آن بر تجارب، ياد كيرى، و شـحصيت كود كان

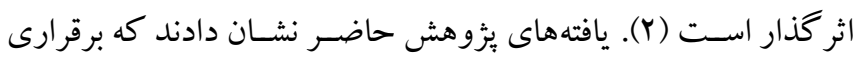

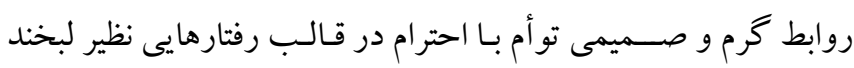

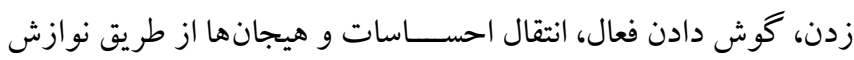

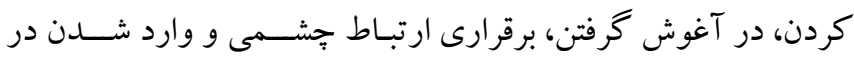

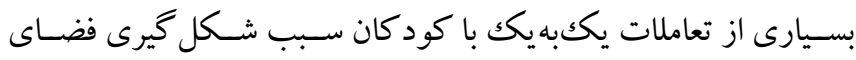


در بايان مضسمون مديريت رفتار از ديخر يافتههاى بثوهش حاضسر

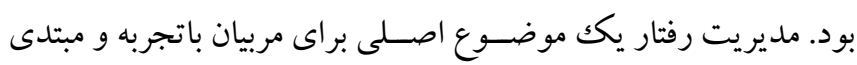

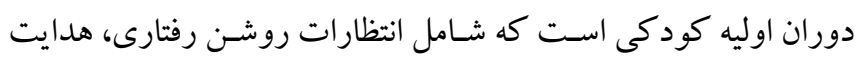
رفتار نادرست، و عدالت و عدم تبعيض است. يافتهاى يُزوهش حاضر

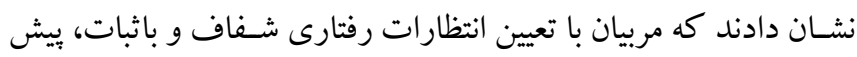

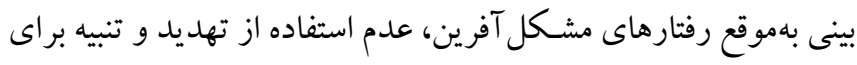

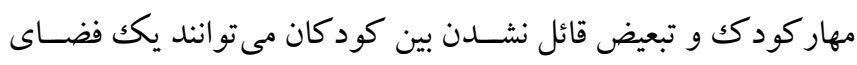

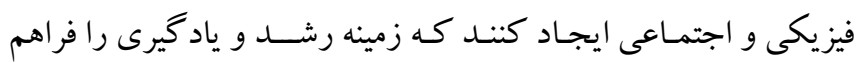

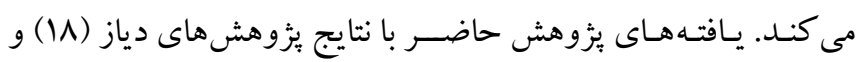

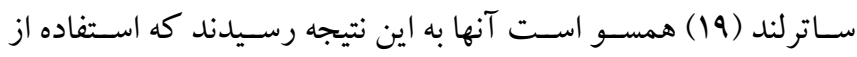

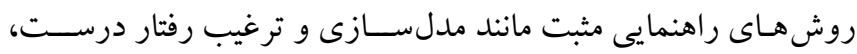

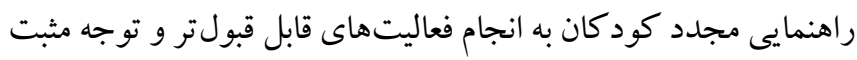

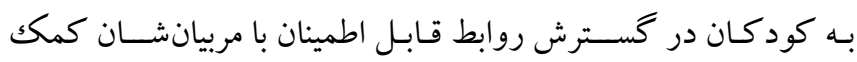

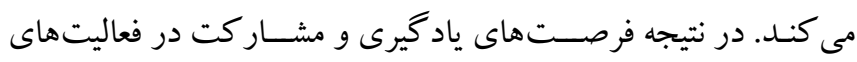
كلاسى بيشترى نصيب اين كود كان مى دود.

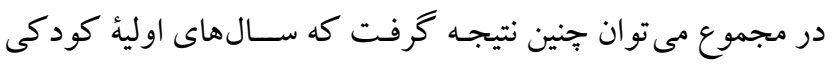

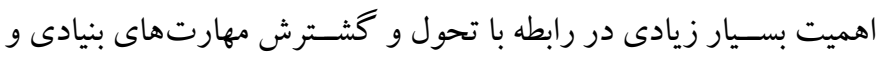

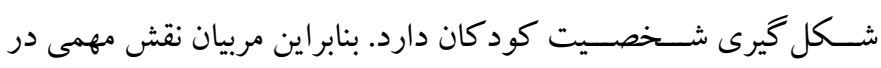

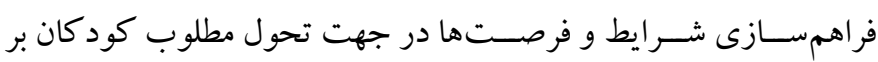

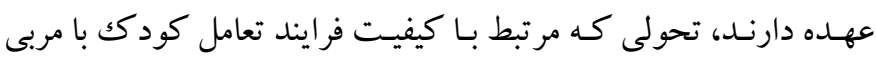
اسـت؛ بنابر اين بسيار مهم است افر ادى با كود كان سنين بيش دبستانى كار

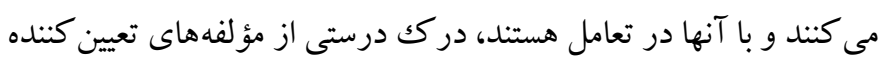
كيفيت فرايند تعامل در محيطى كه كود كان رشد مى كنند، ياد مى كيرند، و فكر مى كنند داشته باشند. از محسدوديـتهاى اين يزوهش مئى توان به انتخاب افر اد نمونه از بين

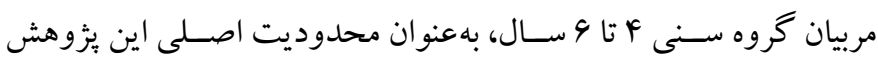

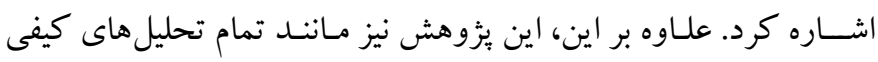

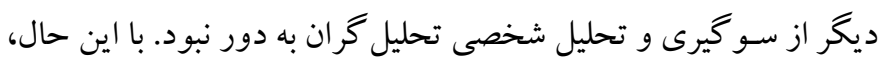

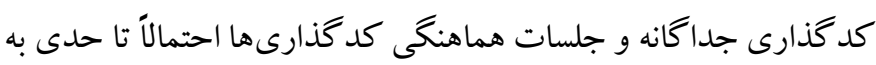

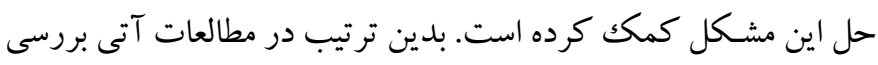

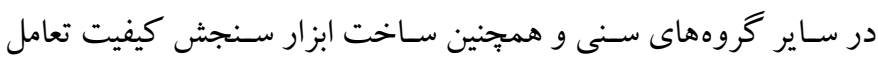

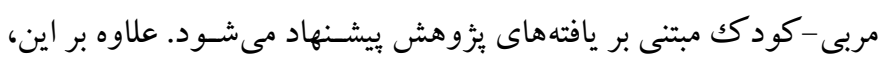

بازخورد بود. يافته هاى يُزوهش حاضسر با نتايج بزّوهش هاوز و همكاران (TD) همسـو اسـت. آنها به اين نتيجه رســيدند كه فعاليت ها و برنامههاى

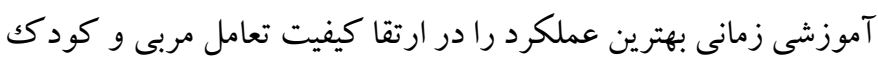

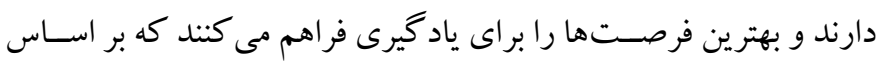

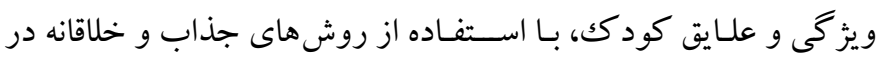
فعاليت ها و ارائه بازخوردهائ ونود مناسب و وبه به موقع به فعاليت كود كان است.

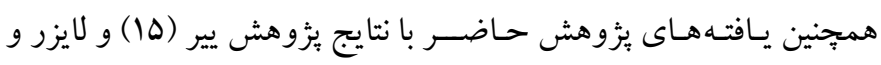

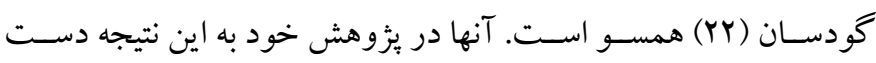

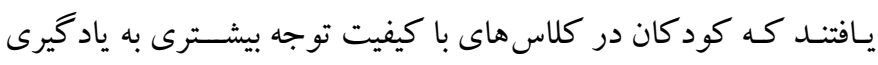
مبـذول مى دارنـد و اين كلاس ها ارتباط مســتقيمى با ياد گيرى آنها دارد.

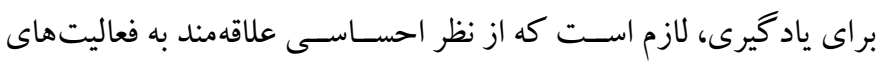

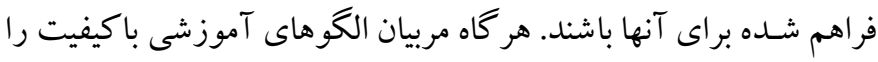

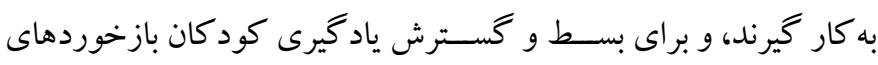

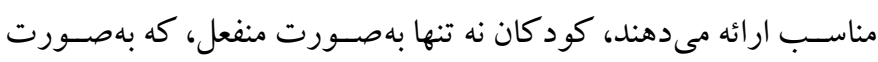
فعالانه نيز در تجربه ياد گيرى شركت مى كنند.

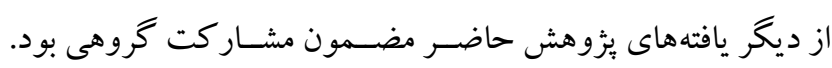

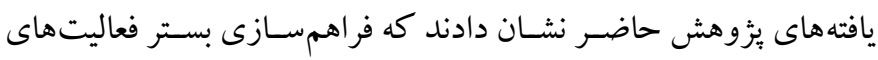

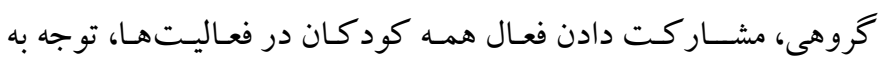

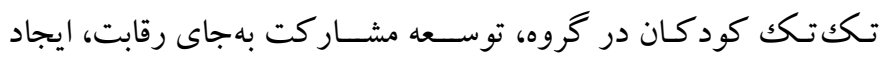

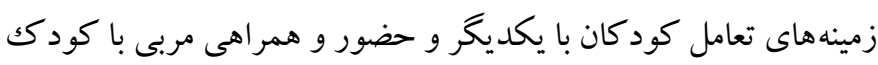

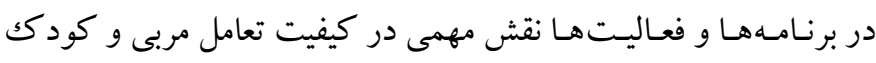

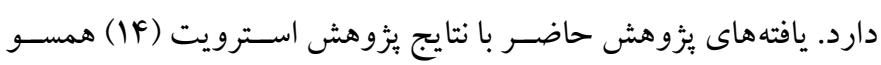

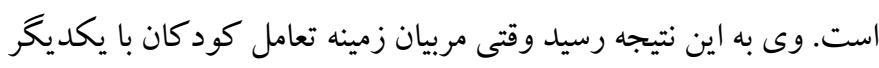

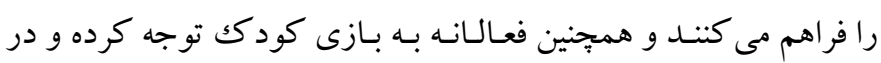
بـازى آنها (بدون تصــرف در بازى) مشــاركت مى كنند و در تجربيات مختلف روزمره با كود كك سهيم مىشوند، به كود كان مىفهماند كه آنها

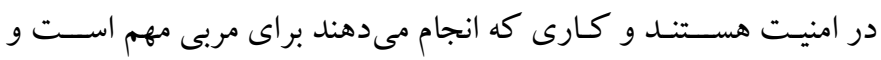

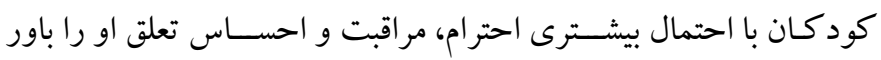

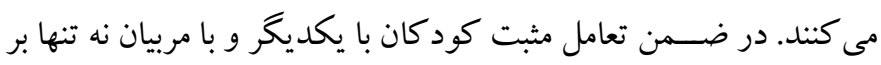

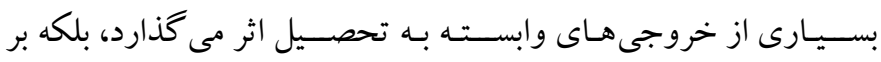

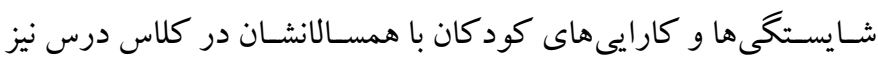
تأثير گذار است. 
شـــه اسـت و تمامى ملاحظات اخلاقى مانند رضـايت كامل افر اد نمونه، رعايت اصـل رازدارى و محر مانه ماندن اطلاعات رعايت شده است. حامى مالى: اين مطالعه بدون حمايت مالى هيج مؤسسه و سازمانى انجام شده است.

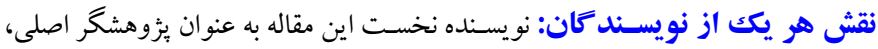

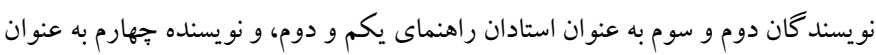
استاد مشاور در اين يزوهش نقش داشتهاند. تضــاد منافع: نويســد گان اعلام مىدارند كه در نتايج اين يُوهش هيج گونه تضــاد منافعى وجود ندارد. تشـكر و قدردانى: بدين وسـيله از اسـتادان محترم، مديران و مربيان مهدهاى كودك شر كت كننده در اين بيزوهش تشكر و قدردانى مى شود.
بيشـنهاد مى شـود از نتايج بثزوهش حاضـر بهعنوان جهارجيوبى براى تأمين مربيان شـايسته و كار آمد در مهلدهاى كودك و همجينين برنامهريزىهاى آموزشى توسط متصديان دستاندر كار مانند سازمان ملى تعليم و تربيت كودك استفاده شود. ملاحظات اخلاقى ييروى از اصــول اخلاق ثزوهش: اين مقاله مربوط به بخشـى از رسـاله دكتراى

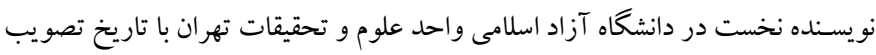

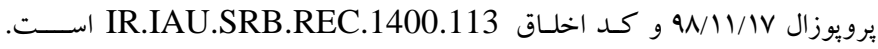

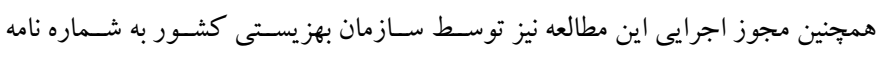

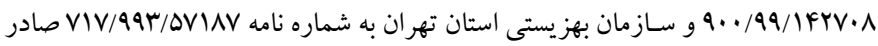




\section{References}

1. Abolmaali Alhosseini K, Naghd bishi E. The role of metacognitive beliefs and difficulties in emotion regulation in job satisfaction of kindergarten mentors. Pre-school and Elementary School Studies, 2016; 2 (5): 47-68. [Persian]. [Link]

2. Fowlkes-Miller L. The impact of child teacher relationship training for early childhood education: The role of the relationship [Thesis for Doctor of Philosophy Counselin]. University of north Texas; 2019, PP: 21-69. [Link]

3. nozohouri R, Fathiazar E, Adib Y, Bafandeh Gharamaleki $H$. The effect of brain-based education on level of learning of pre-schoolers and their linguistic preparedness. Research in Curriculum Planning. 2019; 16 (62): 53-63. [Persian]. [Link]

4. Khodabandeloo R, Mehran G, Mohseni H, Rajabi F. An analytical study of professional development in pre-school education: An overview of the research carried out over the past 36 years. Jornal of New Thoughts on Education. 2019;15 (1): 7-26. [Persian]. [Link]

5. Harms T, Clifford R.M, Cryer D. Early Childhood Environment Rating Scale, Third Edition (ECERS-3). Talaee E, Sajjadian H. (Persian Translator). 3rd Ee. Tehran; Koroush Publication. 2018, pp: 82-92. [Persian]. [Link]

6. Espinosa L. High-Quality pre-school: Why we need it and what it looks like. NIEER pre-school policy matters, Issue 1. New Brunswick, NJ: National institute for early education research. 2002. Available from: URL: http: //nieer. org/resources/policybriefs/1. pdf. [Link]

7. Zare H, Tahmassiyan K, Pakdaman S, Davari Ardakani N, Rahimi T. Observing Iranian mother-child interaction in a playing situation. Journal of Family Research. 2016;12 (45): 7-25. [Persian]. [Link]

8. Hosseinkhah A, Abbasi E, Mosapour N. Pre-school pathology of Iran. Pre-school and elementary school studies. 2016; 2 (6): 1-31. Doi: 10.22054/soece.2018.22077.1127. [Persian]. [Link]

9. Bronfenbrenner U, Morris P. The bioecological model of human development. In: Damon W, Lerner R, Handbook of child psychology, Vol 1: Theoretical models of human development. 6th ed. Hoboken, N. J.: Wiley. 2007, pp: 793828. [Link]

10. Bagheri k. Teaching "to" and "learning from. Journal of fundamentals of education. 2014; 3(2). 5-24. [Persian]. [Link]

11. Colker L. Twelve characteristics of effective early childhood teachers. Young Children on the Web. 2008; 63 (2): 68-73. [Link]

12. Ostrosky M.M, Jung E.Y. Building Positive Teacher-Child Relationships. Project funded by the Child Care and Head Start Bureaus in the U.S. Department of Health and Human. 2012. Available from: URL: http://csefel.uiuc.edu. [Link]

13. Fisher D, Waldrip B, den Brok P. Students' perceptions of primary teachers' interpersonal behavior and of cultural dimensions in the classroom environment. Int $\mathrm{J}$ Educ Res. 2005; 43 (1/2): 25-38. [Link]

14. Stroet K, Opdenakker M, Minnaert A. Need supportive teaching in practice: A narrative analysis in schools with contrasting educational approaches. Soc Psychol Educ, 2015; 18 (3), 585-613. [Link]

15. Yair G. Educational battlefields in America: The tug-of-war over students' engagement with instruction. Sociol Educ. 2000; 73: 247-269. [Link]

16. Abed N, Pakdaman S, Mazaheri M, Heidari M, Tahmassian K. Evaluating the Influence of "Listening to Children Respectfully" Package on Enhancing Children's Wellbeing. Clinical Psychology Studies, 2017; 7 (26): 25-42. [Persian]. [Link]

17. La Paro K, Pianta R, StuhlmannM. The classroom assessment scoring system (CLASS]: Findings from the Prekindergarten Year. Elem Sch J. 2004; 5 (104): 409-426. [Link]

18. Diaz A, Eisenberg N, Valiente C, VanSchyndel S, Spinrad L, Berger R, Southworth J. Relations of positive and negative expressivity and effortful control to kindergarteners' student-teacher relationship, academic engagement, and externalizing problems at school. J Res Pers. 2017; 67: 3-14. [Link]

19. Sutherland K, Conroy M, Algina J, Ladwig C, Gabriel J, Gyure M. Reducing child problem behaviors and improving teacher-child interactions and relationships: A randomized controlled trial of BEST in CLASS. Early Child Res Q. 2018; 42: 31-43. [Link]

20. Lari N, Hejazi E, Joukar B, Ejei J. Phenomenological analysis of students' perception of teacher' $\mathrm{s}$ effective features and actions in teacher-student relationship. J Psychol. 2020;24 (93): 3-22. [Persian]. [Link]

21. Zarei M, Nasr Esfahani A, Mir Shah Jafari E, Liaghtdar M. Pre-school teachers who and with what characteristics? Journal of Theory and Practice in Curriculum.2017; 4 (8): 181-204. [Persian]. [Link]

22. Layzer J, Goodson B. The "quality" of early care and education settings: Definitional and measurement issues. Eval Rev. 2006; 30; 556-577. [Link]

23. Connelly J. Pre-school teacher characteristics: Professional development and classroom quality. [master's thesis]. University of Rhode Island; 2018, pp: 4-17. [Link]

24. Pianta R. C, \& Hamre B. K. Conceptualization, measurement and improvement of classroom processes: Standardized observation can leverage capacity. Educational Researcher. 2009; 38 (2): 109-119. [Link]

25. Howes C, Sidle-Fuligni A, Soliday Hong S, Huang Yiching D, Lara-Cinisomo S. The pre-school instructional context and child-teacher relationships. Early education and development. 2013; 3 (24): 273-291. [Link]

26. Parvari P. The transition from philosophy to methodology, a new reading of the phenomenology method: the foundation of philosophical approaches and 
implementation steps. Sociological studies. 2019; 12 (44): 87-106. [Persian]. [Link]

27. Nazir J. Using phenomenology to conduct environmental education research: Experience and issues. J Environ Educ, 2016; 47 (3): 179-190. [Link]

28. Emami S. A, Dehghan Nayeri n, Rahnavard Z, Nori Saeed A. Qualitative research methodology: phenomenology. J
Holist Nurs Midwifery. 2013; 22 (68): 56-63. [Persian]. [Link]

29. Abbaszadeh M. Validity and reliability in qualitative researches. Journal of applied sociology. 2012; 1 (45): 1934. [Persian]. [link] 